\title{
Tüm Binayı Saran Yangın Sonucunda Çelik Yapıların Dayanımlarının Araştırılması
}

\author{
Mustafa YAĞIMLI ${ }^{1}$ (i) , Mehmet Toyanç YAZGANiD \\ ${ }^{1}$ İstanbul Gedik Üniversitesi, Sağlık Bilimleri Enstitüsü, İş Sağlığı ve Güvenliği, Kartal, İstanbul
}

Geliş / Received: 04/04/2020, Kabul / Accepted: 08/12/2020

\section{$\ddot{O} z$}

Yangına dayanıklı yapı tasarımında, yangının meydana getirdiği olumsuz etkilerinin bilinmesi ve taşıyıcı sistemi oluşturan yapı elemanlarının bu deformasyonlara karşı dayanımlı olmalarının yanında, mimari tasarımdan başlayarak yapının taşıyıcı sisteminin oluşturulmasında, yangın dayanımını arttıracak birçok ayrıntının göz önüne alınması gerekmektedir. Yangın geçirmiş çelik binalarda çelik elemanların mekanik özelliklerinde yangının derecesine göre büyük değişiklikler meydana gelmektedir.

Yangın geçirmiş çelik yapının Doğrusal Olmayan Statik Öteleme(Push-Over) Analizi ile performansının değerlendirilmesi amaçlanmıştır.

Sonuçlar göstermiştir ki çelik yapıların uygun yangın korunum yöntemleri ile dayanımları yapıda bulunanların güvenli bir biçimde terk etmeleri için yeterli zamanı sağlar.

Anahtar Kelimeler: yangın, çelik, bina, dayanım, güvenlik, yapı

\section{Put the Investigation Of Strength Of Steel Structures As A Result Of Fire}

\begin{abstract}
In fire-resistant building design, it is necessary to know the negative effects of fire and the structural elements that make up the bearing system are resistant to these deformations, as well as many details that will increase the fire resistance of the building starting from the architectural design. The mechanical properties of the steel components of those steel buildings, major changes are taking places according to the degree of fire.

It is aimed to evaluate the performance of the fired steel structure with the Non-Linear Static Translation (Push-Over) Analysis.

Results showed that, appropriate fire protection of steel structures and strengths in the structure of those methods safely provide enough time to leave.
\end{abstract}

Keywords: Acacia fire, steel, building, strength, safety, structure 


\section{Giriş}

Günümüzde, başlıca iki tür tasarım felsefesi vardır. Bunlardan birincisi güvenlik gerilmeleri, diğeri ise yük ve dayanım faktörü tasarımı olarak adlandırılırlar. Önceleri güvenlik gerilmeleri esasına dayanan yöntemler kullanılmış olmakla beraber, son yıllarda daha rasyonel ve olasılık esaslı olan sınır değer yöntemlerinin kullanılması yaygınlaşmıştır. Tasarım için değişik sınır değer esaslı yöntemler kullanılmaktadır (Yardımc1, 2005). Yangın yerinde meydana gelen ölüm olaylarının çoğu zehirli gazlar sebebiyle olmaktadır (Strauss, 1989).

Yanmazlık bir yapı malzemesinin, yanmanın gelişimine doğrudan katkıda bulunmama durumudur (Sunar, 1981).

Çelik, demir cevherinden elde edilir. Demir cevheri tabiatta oksit, hidroksit veya karbon ve diğer maddelerle karışık olarak bulunur. Demir plastiktir ve düşük mukavemete sahip olduğundan yap1 konstrüksiyonlarında kullanılmaz. Çeliğin dayanıklılığı muhtelif katkı elemanlarının katılmasıyla arttırılır. Çelikte katkı elemanı fonksiyonunu birkaç kimyasal element yerine getirir. Adi kaliteli çelik demir (Fe) ve karbon (C)' dan ibaret olan karışıma belirli miktarlarda silisyum (Si), alüminyum (AI), manganez (Mn), Krom $(\mathrm{Cr})$ Kolombiyum (Cb), bakır $(\mathrm{Cu})$, Molibden (Mo), Bor (B), Azot (N), Volfram(W), Nikel (Ni) ve Vanadyum (V) katılarak elde edilir (MIT Department of Civil and Environ-mental Engineering, 1999).
Çelik yapıların çok sayıda yapı da kullanılmasının avantajları şöyle sıralanabilir.

a) Döşeme kalınlıkları düşüktür. Çelik yapılar ferah, büyük açıklıklı, işlevsel mekânlardır. Çelik taşıyıcılı yapılar ara kolonsuz, duvarsız ve kesintisiz mekânlardır. Ara kolonlar hiç yoktur veya çok az sayıdadır. Kolon kesitleri çok küçüktür. Örnek olarak betonarmede $100 * 100 \mathrm{~cm}$ olan bir kolonun çelik karşılığı $40^{*} 40$ cm'dir. Bu da daha fazla net kullanım alanı, ofis binaları için yaklaşık \%3-5 net kullanım alanı kazancı demektir. Aynı yapı yüksekliği için daha fazla kat yapılabileceği gibi, temiz kat yüksekliği de daha fazladır.

b) Geçirimsiz bir malzemedir. Emniyet gerilmesinin yüksek olmasına paralel olarak yüksek yoğunluğa sahiptir. Bu nedenle siv1 ve gazların depolanmasında kullanılır.

c) Kısa sürede ve her mevsimde inşa edilebilir. Konstrüksiyonlar iyi donanımlı fabrikalar da hazırlanır. Çeliğin şekil alma olanağı sınırsız olduğundan, taşıyıcı yapı pek çok türde yapılabilir, taşıyıcı yapıda çelik çok çeşitli şekillerde kullanılabilir. Uluslararası ödül alan yapıların çoğunun çelik taşıyıcılı yapılar olması, rastlantı değildir. Çelik yapılar inşaat plânlama ve yönetiminde hızlı inşaat, fast-track paralel ve hızlı yapı programlaması şeklindeki yeni düşünce biçimi, \%100 plânlanabilirlik, \%100 kontrol sağlayacaktır.

d) Tüm elemanlar kesin ölçüsündedir. Çelik yapısal elemanların hepsi endüstriyel önüretimlidir. Toleranslar $\mathrm{mm}$ mertebesinde 
olduğundan montaj sorunsuz ve kusuruzdur. Şantiyede tamirat gerektirmez. Çelik yapı kuru yöntemlerle yapılır Kolay kurulur, temiz ve hizlı yapılır.

e) Çelik yapıların ömürleri uzun, kullanımı esnek, yenilenmesi kolaydır. Kullanım süresi içinde kullanım amaçları değişebilir. Binada mal sahibi veya kiracı olsun, kullanıcıların istekleri zaman içinde değişebilir. Bu nedenle binada hacimler kullanım açısından esnek olmalıdır. Çelik her amaca uygun değişimler yapılmasına olanak verir. Bina taşıyıcı yapısının ömrü 50-100 yıldır. Çelik yapıda tesisat bölgelerine kolay ulaşılır, bakım ve yenileme çok kolay yapılır. Bina ömrüyle karşılaştırıldığında diğer yapı katmanlarının ömürleri daha kısadır. Örnek olarak tesisat ömrü ortalama 10 yıl kadardır. Çelik yapıda tesisat montajı çok kolay yapılır ve gerektiğinde çok da rahat yenilenir. Bilgisayar kabloları, haberleşme sistemleri gibi diğer teknolojik donanımın ömrü 2-3 yıl kadar kısadır. Çelik yapılarda bu tür sık yenilemeler sorunsuzca gerçekleştirilebilir. Döşeme iç hacimleri boş olduğundan bu boşluk, tüm tesisatı geçirmek için kullanılır. Ayrıca döşemede istenilen yerden çıkışlar için delik açılabilir, yer değiştirmeler sağlanabilir. Yapı ihtiyaç plânlamasında uzun verimli düşünmek gerekir. Kullanıcı ve değişiklik isteklerine çözümler kolay ve hızla uygulanabilir olmalıdır. $\mathrm{Bu}$ anlamda çelik göz önünde tutulması gereken, özel bir yapı malzemesidir. Çelik yapılar değişiklik isteklerine sonsuz çözümler sağlar. Çelik taşıyıcı yapı değişiklik isteklerine kolaylıkla uyum sağlar. Engelsiz hacimler kolayca bölümlenebilir. Kuru yap1 yöntemi nedeniyle uygulama kolaylığı vardır. Doğru tasarlanmak kaydıyla, işlev ve dayanımından bir şey yitirmeden, tümü görünür olan taşıyıcı yapı elemanlarını güçlendirmek, tamir etmek, yenilemek ve/veya değiştirmek olanăğ vardır. Yapıya yatay ve dikey ekler yapılabilir, yeni katlar eklenebilir, belirli elemanlar veya bölümler kaldırılabilir. Hatta geçmiş pek çok örnekte olduğu gibi yapının tümüyle sökülüp başka bir yere taşınması olanağı vardır. Çelik taşıyıcılı yapılar hem restorasyona açıktır hem de diğer tür yapıların restorasyonunda pek çok olanaklar sunar.

f) Çelik taşıyıcı yapı yüksek dayanımlıdır. Çelik taşıyıcı yapı depreme dayanıklıdır. Deprem dayanımında tasarım hedefleri önemlidir. Bilindiği gibi yapının önemine göre deprem dayanımı tasarımı yapılır. Aynı oranda daha az deprem yükü alır. Çelik taşıyıc1 yap1 elemanları sünek olduğundan üzerlerine düşen enerjiyi çok iyi sönümlerler. Hasar almadan üzerlerine düşen enerjiyi soğurabilir ve bunu yaparken taşıyıcı yeteneklerini ve duyarlılıklarını yitirmezler. Ayrica beklenenin ötesinde şiddette bir deprem olması halinde, plastik tasarım yöntemleri sayesinde hasar kontrol altında tutulabilir. Tasarımla belirlenmiş plastik mafsallar oluşmasına izin verilerek, aşırı yük sigortaları oluşturulabilir. $\mathrm{Bu}$ hem daha ekonomik deprem tasarımı hem de hasar varsa, tamir gerekiyorsa kolay, çabuk, güvenilir olarak tamir yapılmasını sağlar. Burada öncelik sırasına göre amaçlanan: göçmeyi önlemek, can ve mal kurtarmak ve olabiliyorsa yapıyı daha sonra tamir ederek kurtarmaktır. Ancak bu isteklere hizmet verebilirlik kriterini de eklersek, yani yapımızın deprem sirasında ve depremden hemen sonra kullanılabilir olmasinı da isteyeceksek, o zaman taşıyıcı yapıda mutlaka çelik kullanılmalıdır. Emniyetlidir; hesaplarda göz önüne alınan homojen ve izotrop cisim kabulüne çok uygun olduğundan kendisinden beklenen davranışı gösterir. Çelik taşıyıcılı yapı tümüyle çelik olabileceği gibi, çelik ağırlıklı beton veya 
beton çekirdek çelik kolon, kiriş ya da beton ağırlıklı çelik bileşik (kompozit) sistem de olabilir. Döşemeler genelde beton kompozit tarzda yaklaşık $12 \mathrm{~cm}$ kalınlığında yerinde dökülür. Ayrıca boşluklu beton paneller veya prekast plaklar kullanarak biraz daha ağır döşeme çözümleri de vardır. Özellikle az katlı yapılarda çok hafif ve \%100 kuru yöntemle ahşap (OSB) döşemeler de yapılır.

g) Çelik taşıyıcı yapı çok hafiftir. Kütlesi aynı kapalı alana sahip betonarme yapıya göre \%40-50 daha azdır.

h) Çelik tüm yapı malzemeleri gibi yangın 1sısından etkilenir. Çelik de tüm yapılar ve yap1 malzemeleri gibi yangın etkilerinden korunmalıdır. Yaygın kanının aksine betonarme de yangına karşı korunmalıdır (Fransa ve Belçika Yangın Şartnameleri, İsviçre Alpleri tünel yangınları örneklerinde olduğu gibi). Her tür yapıda yangın mühendisliği tasarımı yapılmalıdır. Çeliği korumak için çeşitli yöntemler vardır. Yangın söndürme, engelleme, bölümleme gibi aktif sistemlerin yanı sıra alçı sıva, alçı kaplama, yanmaz boya ve 1s1 yalitım kaplamaları pasif sistemler de geliştirilmiştir. $\mathrm{Bu}$ sistemlerin hepsi Türkiye'de uygulanıyor ve uygulamacıları vardır. Mimari gereklere göre seçimleri yapılır. Uygulaması kolaydır.

I) Çelik yapı ekonomiktir. Ekonomiklik önemlidir. Öncelikle "Ucuz ekonomik değildir" saptamasını yapmak gerekir. "Bir $\mathrm{m}^{2}$ kaça geliyor?" sorusu ekonomiklik ölçütü değildir. Ekonomikliği anlamak için projeye bütünsel bakış gereklidir. Doğrudan ve dolaylı tüm fayda ve kazançlar düşünülmelidir. Ekonomiklik projenin tüm ömrü boyunca değerlendirilmelidir. Toplam ekonomiklik sadece yapım sirasında ekonomiklikle değil, kullanım sırasında ekonomiklikle de belirlenir. Ekonomiklik için malzemenin özeliklerine uygun tasarım şarttır. Betonarme projeyi aynen çelik yapmak ekonomik değildir. Öncelikle yapının mimarisi çeliğe uygun olmalıdır. Maliyet hesabı doğru yapılmalıdır. Bitmiş yapının tüm maliyetine, yani bitmiş proje bedeline \%100 dersek, taşıyıcı yapının bu toplam içindeki payı yapı türüne göre \%5\%30 arasında değişir. Başka bir ifadeyle taşıyıcı karkas maliyeti tüm proje maliyetinin sadece bir kısmıdır. Karkas bedelinin \%20\%30 daha fazla veya az olmas1, tüm proje maliyetini en fazla \%1-\%9 arttırır. Çelik yapıların çok kısa zamanda yapılması, bu nedenle yapım süresinin alışılmış yöntemlere göre yarıya hatta üçte bire inmesi, çok büyük zaman kazancı sağlar. Ayrıca hava koşullarından ve mevsimlerden bağımsız, kış şartları da dahil inşaat yapılabiliyor olması, bu hızlılığ 1 perçinler. $\mathrm{Bu}$ nedenle dolaylı maliyetlerin (şantiye, işçilik, kira, vb) hepsi de belirgin bir şekilde azalır. Tüm bunlar yüksek parasal kazanç demektir.

i) Binanın pazarlanabilirliği çok önemlidir. Gayrimenkul piyasasındaki dalgalanmalar yapınızın doğru zamanda pazara girmesini zorunlu kılar. Dalgayı tepe noktasında yakalayabilmek için yapım süresinin çok kısa olması gerekir. $\mathrm{Bu}$ da binanın pazarlanabilirliğini arttırır (Tabak, 2003).

Ayrıca, çeliğin yüksek sıcaklıklara maruz kaldığı uzun süreler göz önüne alındığında, göçme durumunun yaşanmaması dikkat çekicidir. $\mathrm{Bu}$ durumda, çeliğin yerel kompartıman yangınlarında beklenenden çok daha mukavim (dayanıklı) olduğu gerçeği ile karşılaşılmıştır (Öven ve Parlak, 2003).

Çeliğin elastisite modülü ve akma gerilmesi ikisi sıcaklığın artmasıyla önemli bir biçimde azalan kapasite taşıma yükünü tanımlamak için çok önemlidir (Saha, 2004). 
Çelik yapıların yangın güvenliği geçmişte yaşanmış en önemli örneklerden birisi Dünya Ticaret Merkezi'nin 11 Eylül 2001 günü yıkılmasından sonra çelik taşıyıcılı binaların yangına dayanımı konusunda yapılan araştırmalardı. Yakın bir tarihte de Tahran'daki çelik taşıyıcılı Plasco binası yangın sırasında çöktü. Dünya Ticaret Merkezi'nin ve Plasco binasının taşıyıcıları çelik olduğu için çöktüğünü söylemek doğru olmaz. Örneğin, Dünya Ticaret Merkezi'nin çökmesine çarpmanın oluşturduğu sarsintı sonrasında uçaktaki $91 \mathrm{~m}^{3}$ (73 ton) jet yakıtının oluşturduğu sıcaklık neden olmuştur. 2007 y1lı içinde yanan Plasco binası ise 1962 yılında yapılan, yağmurlama sistemi ve hiçbir yangın koruması olmayan binadır.

Yangında hasar görerek çöken çelik, betonarme, briket ve ahşap birçok bina bulunmaktadır. 1970-2002 yılları arasında yangın sırasında çöken 22 binanın taşıyıcıları yapı malzemelerine göre sinıflandırıldığında; 7 binanın betonarme, 6 binanın çelik, 5 binanın tuğla, 2 binanın ahşap olduğu ve 2 binanın taşıyıcısının belirlenmediği görülmektedir (Beitel and Iwankiw 2005). Bu binalardan, 9 bina ofis, 8 bina konut, 3 bina ticaret ve 2 bina çok amaçlı olarak kullanılmaktadır. Bunlar içerisinde 6 binanın kat sayıs1 21 kattan daha fazladır. Görüldüğü gibi, sadece çelik taşıyıcılı binaların yangında çöktüğünü düşünmemelidir. Binanın yap1 malzemesine uygun koruma önlemlerinin alınmaması durumunda bütün binalar yangında çökebilmektedir (K1lıç, 2017).

Avrupa Birliği Yapı Malzemeleri Direktifi'ne (89/106/EEC) göre, yapıların teknik özelliklerini etkileyen altı temel unsurdan birincisi mekanik dayanım, ikincisi ise yangın durumunda emniyettir (Beitel and Iwankiw 2005). Bu direktif, büyük binaların projelerinde yapının bir yangın durumunda çökmemesi için korunma esaslarını temel tasarım kıstaslarıdır.

Yanan ve kısmen veya tamamen çöken önemli yüksek binalar, taşıyıcı malzemeleri, kat sayıları, kullanım amaçları ve hasar durumu Tablo 1'de verilmiştir. Dünya Ticaret Merkezi haricinde çöken binaların hiçbirinde yağmurlama, pasif ve muhtemel koruma tedbirlerlerinin bulunmadığ söylenebilmek-tedir (K1lıç, 2017).

Özellikle; yangın yükünün fazla olduğu binalarda, yangın esnasında ani bir çökmenin engellenebilmesi için taşıyıcı sistem seçimi çok önemlidir. Seçilen taşıyıcı sistemin gerekli koşulları sağlayabilecek yangın dayanımına sahip hale getirilmesi, gerek bina kullanıcıları, gerekse itfaiye ekiplerinin can güvenliği açısından kaçınılmaz bir gerekliliktir. Betonarme, çelik ve ahşap taşıyıcı sistemlerin yangın anındaki davranışlarının bilinmesi bu gerekliliği sağlamada çok büyük yardımcı olacaktır (Özgünler, 1994). Yapı dışında bulunan çelik elemanlar yap1 içinde bulunanlara oranla daha soğuk olacaktır. Bu da, çelik dış yapı bileşenlerinin korumasız olarak kullanımına olanak sağlamaktadır. Isının, yapı dışında kalan bileşenlere iletilmesi, alevin davranışına, sıcaklık derecesine, yapı bileşenlerinin pozisyonuna ve yangın yüküne bağlı olduğu kadar pencere açıklıklarının boyutları ve yerlerine de bağlıdır (Fire protection of steel structures, 2014).

$\mathrm{Bu}$ çalışmanın amacı; yangın geçirmiş çelik binaların yanal dayanımları ve rijitliklerindeki değişimlerin bulunmasıdır. $\mathrm{Bu}$ amaçla, 9 katlı bir çelik yapının farklı derecelerdeki yangınlara maruz kaldığ edilmiştir. Yangın geçirmiş çelik binanın malzeme özellikleri değiştirilerek yanal 
dayanımı ve rijitliğindeki değişimler

bulunmaya çalışıl-mıştır.

Tablo 1. Yanan yüksek binalarda taşıyıcı sistem ve hasar durumu (Kılıç, 2017)

\begin{tabular}{|c|c|c|c|c|c|c|}
\hline Bina Adı & Yer & Taşıyıcı & Kat & $\begin{array}{l}\text { Kullanım } \\
\text { Sekli }\end{array}$ & $\begin{array}{l}\text { Yangın } \\
\text { Tarihi }\end{array}$ & $\begin{array}{l}\text { Çöken } \\
\text { Kısım }\end{array}$ \\
\hline Plasco Binası & Tahran, İran & Çelik & 17 & Ofis & $\begin{array}{l}19 \text { Ocak } \\
2017\end{array}$ & Tamamen \\
\hline $\begin{array}{l}\text { Mandarin } \\
\text { Hotel }\end{array}$ & Pekin, Çin & Çelik & 34 & Otel & $\begin{array}{l}9 \quad \text { Şubat } \\
2009\end{array}$ & $\begin{array}{l}\text { Çökme- } \\
\text { yok }\end{array}$ \\
\hline $\begin{array}{l}\text { Development } \\
\text { Bank }\end{array}$ & $\begin{array}{l}\text { Lagos, } \\
\text { Nijerya }\end{array}$ & Betonarme & 21 & Ofis & $\begin{array}{l}22 \text { Mart } \\
2006\end{array}$ & $\begin{array}{l}\text { Kismen } \\
(<9 \text { kat })\end{array}$ \\
\hline $\begin{array}{l}\text { Windsor } \\
\text { Building }\end{array}$ & $\begin{array}{l}\text { Madrid, } \\
\text { Ispanya }\end{array}$ & $\begin{array}{l}\text { Betonarme } \\
\text { ve Celik }\end{array}$ & 32 & Ofis & $\begin{array}{l}13 \text { Şubat } \\
2005\end{array}$ & Tamamen \\
\hline $\begin{array}{l}\text { Caracas } \\
\text { Parque }\end{array}$ & $\begin{array}{l}\text { Caracas, } \\
\text { Venezuala }\end{array}$ & Çelik & 56 & Konut & $\begin{array}{l}\text { Ocak } \\
2004\end{array}$ & $\begin{array}{l}\text { K1smen(2 } \\
\text { kat) }\end{array}$ \\
\hline Apartment & $\begin{array}{l}\text { St Petersburg, } \\
\text { Rusya }\end{array}$ & Betonarme & 9 & Konut & $\begin{array}{l}3 \text { Haziran } \\
2002\end{array}$ & Tamamen \\
\hline Jackson Street & $\begin{array}{l}\text { Hamilton, } \\
\text { Kanada }\end{array}$ & Betonarme & 21 & Konut & $\begin{array}{l}8 \text { Şubat } \\
2002\end{array}$ & Kismen \\
\hline WTC Towers & $\begin{array}{ll}\text { New } & \text { York, } \\
\text { USA } & \\
\end{array}$ & Çelik & 110 & Ofis & $\begin{array}{l}11 \text { Eylül } \\
2001\end{array}$ & Tamamen \\
\hline CESP, Sede 2 & $\begin{array}{l}\text { Sao Paulo, } \\
\text { Brezilya }\end{array}$ & Betonarme & 21 & Ofis & $\begin{array}{l}21 \text { Mayıs } \\
1987\end{array}$ & Kismen \\
\hline $\begin{array}{l}\text { Alexis Nihon } \\
\text { Plaza }\end{array}$ & $\begin{array}{l}\text { Montreal, } \\
\text { Kanada }\end{array}$ & $\begin{array}{l}\text { Kınşter } \\
\text { Çelik }\end{array}$ & 15 & Ofis & $\begin{array}{l}26 \text { Ekim } \\
1986\end{array}$ & 11. kat \\
\hline $\begin{array}{l}\text { Department } \\
\text { Store }\end{array}$ & $\begin{array}{l}\text { Atina, } \\
\text { Yunanistan }\end{array}$ & Betonarme & 18 & Ticaret & $\begin{array}{l}19 \text { Aralık } \\
1980\end{array}$ & 5-8 katlar \\
\hline One $\quad$ New & NewYork, & Kirişler & 50 & Ofis & 5 & $33-34$ \\
\hline $\begin{array}{l}\text { One Meridien } \\
\text { Plaza }\end{array}$ & $\begin{array}{l}\text { Philadelphia, } \\
\text { USA }\end{array}$ & Çelik & 38 & Ofis & $\begin{array}{l}23-24 \\
\text { Şubat }\end{array}$ & $\begin{array}{ll}9 & \text { kat } \\
\text { hasarlı } & \end{array}$ \\
\hline $\begin{array}{l}\text { Mercantile } \\
\text { Insurance }\end{array}$ & Churchill, UK & $\begin{array}{l}\text { Kompozit } \\
\text { Çelik }\end{array}$ & 12 & Ofis & 1991 & 8-10 katlar \\
\hline $\begin{array}{l}\text { First Interstate } \\
\text { Bank }\end{array}$ & $\begin{array}{l}\text { Los Angeles. } \\
\text { USA }\end{array}$ & $\begin{array}{l}\text { Kirişler } \\
\text { Çelik }\end{array}$ & 62 & Ofis & $\begin{array}{l}4 \quad \text { Mayıs } \\
1988\end{array}$ & $\begin{array}{l}4 \text { kat } \\
\text { hasarlı }\end{array}$ \\
\hline $\begin{array}{l}\text { Andraus } \\
\text { Building }\end{array}$ & $\begin{array}{l}\text { Sao Paulo, } \\
\text { Brezilya }\end{array}$ & Betonarme & 31 & Ofis & $\begin{array}{l}24 \text { Şubat } \\
1972\end{array}$ & $\begin{array}{l}\text { Diş } \\
\text { duvarlar }\end{array}$ \\
\hline $\begin{array}{l}\text { Joelma } \\
\text { Crefesul }\end{array}$ & $\begin{array}{l}\text { Sao Paulo, } \\
\text { Brezilya }\end{array}$ & Betonarme & 25 & Ofis & $\begin{array}{l}1 \text { Şubat } \\
1974\end{array}$ & $\begin{array}{l}\text { Diş } \\
\text { duvarlar }\end{array}$ \\
\hline
\end{tabular}




\section{Metot}

$\mathrm{Bu}$ çalışmanın metodu aşağıdaki gibidir:

a.9 katlı binaya ait bir moment çerçevesi seçilmiştir ve yanal dayanımının belirlenmesi için doğrusal olmayan statik öteleme (pushover) analizleri yapılmıştır.

b.Tüm binada farklı derecelerde yangın çıkması sonucunda kiriş ve kolonlarda meydana gelebilecek malzeme özellikleri değiştirilerek yapısal model modifiye edilmiş ve tekrar doğrusal olmayan statik öteleme (push-over) analizi yapılmıştır.

c.Yangın geçirmemiş ve yangın geçirmiş çerçevenin yanal dayanımları ve rijitliklerindeki değişiklikler karşılaştırılmıştır.

\section{Yöntem}

\subsection{Doğrusal Olmayan Statik Öteleme (Push-Over) Analizi}

Son dönemde yapıların performansa dayalı tasarım ve değerlendirilmesi amacıyla doğrusal olmayan statik öteleme analiz yöntemlerinin kullanımı hızla yaygınlaşmaktadır. Doğrusal olmayan statik öteleme analiz yöntemlerinin temeli, yapının yatay kuvvet taşıma kapasitesini ifade eden kapasite eğrisinin belirlenmesini, bu kapasite eğrisinden yapının elastik olmayan maksimum deplasmanının (deplasman talebinin) hesaplanmasını ve bu deplasman değerine kadar statik olarak itilmiş yapının performansının belirlenmesini içermektedir (Öven ve Parlak, 2003). Yapiların performansının değerlendirilmesinde doğru- sal olmayan statik analiz yöntemlerinden yaygın olarak kullanılanları Deplasman Katsayıları Yöntemi (DKY) ve Kapasite Spektrum Yöntemi'dir (KSY).

Deplasman Katsayısı Yöntemi: Bu yöntemde belirli yatay kuvvet için yapıya yüklenen deplasman talebi ile yapının yatay yük taşıma kapasitesinin birbirine bağımlı olduğu esasına dayanmaktadır.

Ancak, deplasman talebi grafiksel olarak değil direkt olarak sayısal bir yöntemle hesaplanmaktadır. Buna göre, deplasman talebi yap1 sisteminin özelliklerine bağlı olarak belirlenen ve yapının periyodunu, histeristik davranışını, ikinci mertebe etkilerini temsil eden katsayılar $\left(\mathrm{C}_{0}, \mathrm{C}_{1}, \mathrm{C}_{2}, \mathrm{C}_{3}\right)$ kullanılarak hesaplanmaktadır. $\mathrm{Bu}$ yöntem yapının kapasite eğrisinin belirlenmesi, maksimum deplasmanın (hedef deplasmanı) hesaplanmasi ve performans seviyesinin belirlenmesi aşamalarından oluşmaktadır.

Kapasite Spektrumu Yöntemi: Kapasite spektrum yöntemi, yapının genel kuvvet deplasman spektrum eğrisi ile talep spektrum eğrisinin indirgenmesi ile elde edilen indirgenmiş tasarım spektrumu eğrisinin grafiksel olarak bir arada görülmesini sağlamaktadır. Kapasite spektrumu yönteminde, yapıda meydana gelen elastik olmayan deformasyonlara bağlı olarak elastik talep spektrumu indirgenerek kapasite ve talebin eşit olduğu nokta belirlenmektedir. Performans noktası adı verilen bu noktada yapıdan istenen performans hedefinin gerçekleşip gerçekleşmediği kontrol edilmektedir. 
$\mathrm{Bu}$ yöntem ile yapıların performansının değerlendirilmesi üç aşamada gerçekleştirilmektedir.

Bu üç aşama sırasıyla aşağıda verilmiştir.

1) Yapının yatay yükler altındaki dayanımını temsil eden ve kapasite eğrisi (doğrusal olmayan statik öteleme (push-over) eğrisi) olarak isimlendirilen yatay kuvvet-deplasman ilişkisinin belirlenmesi:

Birinci aşamada, kapasite eğrisini (doğrusal olmayan statik öteleme(push-over) eğrisini) elde edebilmek için yapının malzeme ve geometri değişimi bakımından lineer olmayan teoriye göre doğrusal olmayan statik öteleme analizi yapılır ve bu Doğrusal Olmayan Statik Öteleme(Push-Over) Analizi olarak adlandı-rılır.

Doğrusal Olmayan Statik Öteleme (Pushover)Analizi: Bir yapının yüksekliği boyunca dağılan artımsal yanal statik yükleme yöntemidir. Yöntemde doğrusal ve elastik olmayan statik analiz yapılır ve yapının üst kat deplasmanı ile taban kesme kuvvetinin değişimini veren yük-deplasman grafiği çizilir. Her yük değeri için toplam taban kesme kuvveti (VT) ve buna karşılık gelen en üst kat yatay deplasmanı ( $\delta$ max)(tepe deplasmanı) arasındaki grafik aşağıdaki gibi elde edilir(Şekil 1) (İrtem vd., 2003).
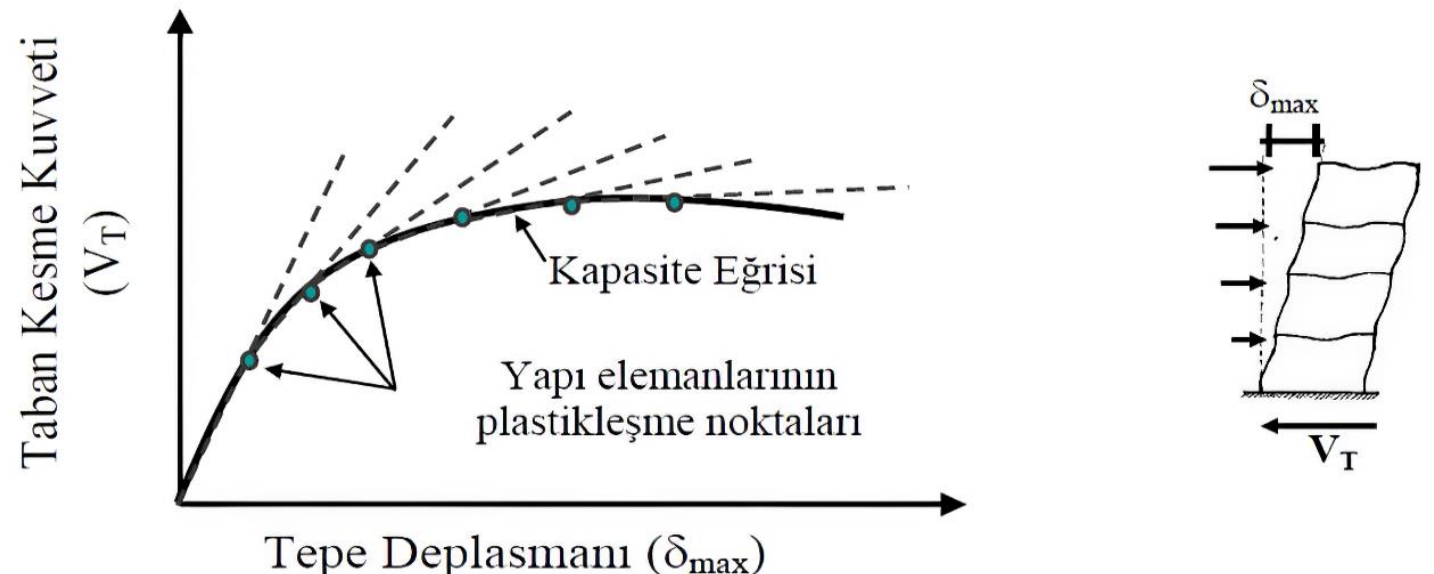

Şekil 1 Lineer olmayan teori ile kapasite eğrisinin elde edilmesi (İrtem vd., 2003)

Hesaplarda plastik şekil değiştirmelerin plastik kesit adı verilen belirli bölgelerde toplandığı bunun dişındaki bölgelerde davranışın doğrusal-elastik olduğu kabul edilir. Kirişlerde plastikleşmenin sadece eğilme momenti ile meydana geldiği, kolonlarda ise iki eksendeki eğilme momenti ile normal kuvvetin etkileşimi ile meydana geldiği kabul edilir. Kolon ve kiriş elemanlarında burulma ve kesme kuvvetinin taşıma kapasitesini aşıp aşmadığı bağımsız olarak kontrol edilir. Yöntem, talep dağılımı, yapı sünekliği, dayanımı ve deformasyonu hakkında bilgi sağlar. Detaylandırma ve tasarım aşamasında önemli olan sınır duruma yaklaşan kritik elemanları tanımlanmasını sağlamaktadır.

2) Göz önüne alınan tehlike seviyesi için yapının maksimum elastik olmayan deplasmanının (deplasman talebinin) belirlen-mesi: KSY'de maksimum deplasman değeri, yapıda meydana gelen plastik deformas-yonlara bağlı olarak elastik talep 
spektrumunun indirgenmesiyle belirlenirken (Şekil 2a), DKY'nde performans düzeyinin kontrol edileceği nokta (hedef deplasmani) (Şekil 2b). Kapasite eğrisinin belirlenmesi ve performans düzeyinin belirlenmesi işlemleri her iki yöntemde de aynıdır. Şekil 2b'deki eğride birincisinin eğimi başlangıç (elastik) rijitliği (Ke), ikincisinin eğimi akma sonrası

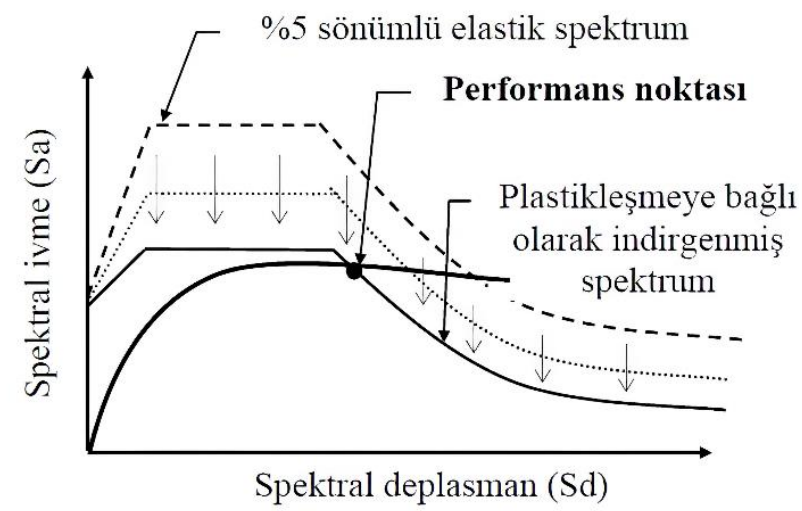

a)KSY ile elastik olmayan talep spektrumu esas alınarak bazı katsayılar ile belirlenmektedir. (elastoplastik) rijitliği (Ks) temsil eden iki doğru parçası ile idealleştirilir. $\mathrm{Vy}$ ise yapının dayanımını ifade eder (Şekil 2b) (İrtem vd., 2003).

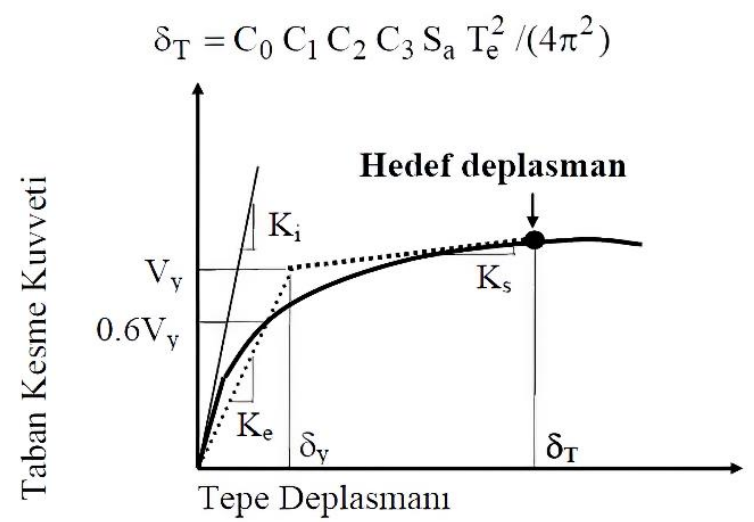

Şekil 2 Maksimum Deplasmanın Belirlenmesi (İrtem vd., 2003)

3) Belirlenen deplasman talebine ulaşmış yapının performans düzeyinin belirlenmesi: Performans kontrolünün yapılacağı yapının maksimum deplasmanı belirlendikten sonra maksimum tepe deplasmanı değeri ve yapı elemanlarının iç kuvvet-şekil değiştirme

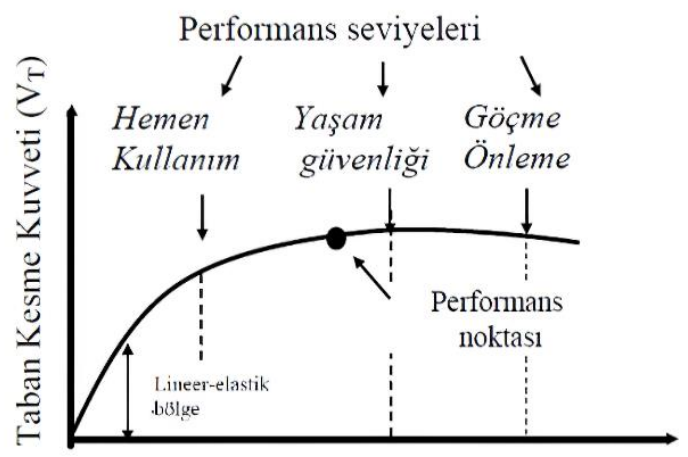

Tepe Deplasmanı $\left(\delta_{\max }\right)$ durumları sınır değerler ile karşılaştırılarak yapının performans seviyesi belirlenmektedir (Şekil 3) (İrtem vd., 2003). Bu çalışmada ortam sıcaklıklar altında dayanım ve rijitlik ilişkisi incelenecektir.

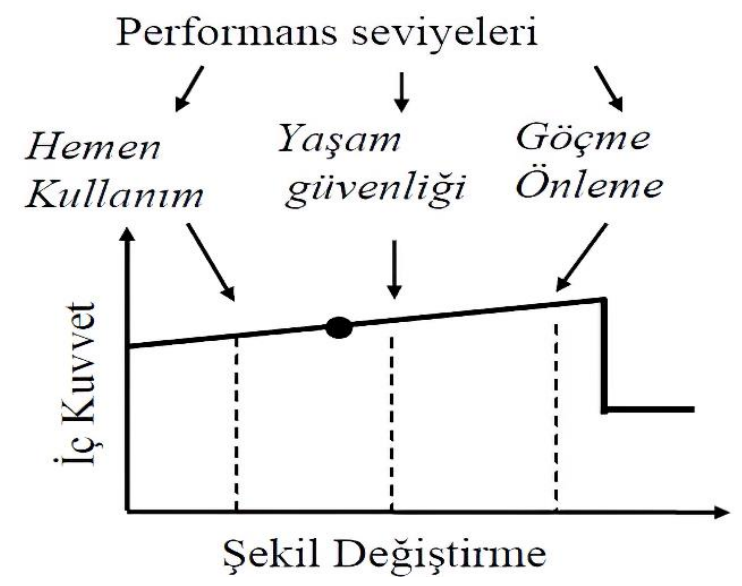

Şekil 3 Performans seviyesinin belirlenmesi (İrtem vd., 2003) 
Doğrusal olmayan statik öteleme (push-over) analizinin yapılma amac1 ana hatlarıyla aşağıdaki gibi özetlenebilir (Öven ve Parlak, 2003):

-Yapı sisteminin artan yatay yükler altında doğrusal olmayan davranışının ve göçme şeklinin belirlenmesi,

-oluşan plastik kesitlerin türleri ve yap1 içindeki dağılımının belirlenmesi (hasar dağılımının belirlenmesi),

•toplam ve göreceli yer değiştirmelerin belirlenmesi,

•yapı sisteminin süneklik düzeyi hakkında bilgi edinmek,

-plastik kesitlerdeki şekil değiştirmeleri belirlemek.

\subsection{9-Katlı Süneklik Düzeyi Yüksek Moment Çerçeve}

Bu çalışmada kullanılan moment çerçevesi, 9 katlı süneklik düzeyi yüksek çelik moment çerçevesidir. 9 katlı çerçevelerin plan ve kesitleri Şekil 4'de verilmiştir. Kolon ek yerleri her iki katta bir düzenlenmiştir.

Bina, düşey yüklere ve deprem yüklerine göre tasarlanmıştır. $\mathrm{Bu}$ dizaynda katlar için $4.59 \mathrm{kN} / \mathrm{m}^{2}$ ölü yük ve $2.39 \mathrm{kN} / \mathrm{m}^{2}$ hareketli yük, çatılar için $3.97 \mathrm{kN} / \mathrm{m}^{2}$ ölü yük ve 0.95 $\mathrm{kN} / \mathrm{m}^{2}$ hareketli yük alınmıştır. Binanın taşıyıcı sistemi bir doğrultuda süneklik düzeyi yüksek moment çerçeveleri, diğer doğrultuda dışmerkez çaprazlı çerçevelerden ve düşey yük taşıyan iç çerçevelerden oluşmaktadır.

Binanın bodrum katındaki duvarları yapının yatay yer değiştirmesini engellediği kabul edilmiştir. Binalar Los Angeles'1n merkezinde $S_{s}$ değerinin $\% 200 g$ ve $S_{1}$ değerinin $\% 100 \mathrm{~g}$ olduğu bölge için tasarlanmıştır. Süneklik düzeyi yüksek moment çerçevesi için taşıyıcı sistem davranışı $\mathrm{R}=8$ alınmıştır.

Taban kesme kuvveti 8656.24 kN bulunmuştur. Kiriş ve kolon elemanların boyutları Tablo 2'de verilmiştir.

Bütün kolonların ve kirişlerin akma gerilmesi minimum akma gerilmesi olan 34.4738(Fe52)kN/Mm² olarak alınmıştır. Binada kat döşemeleri diyafram hareketini sağlamaktadır. Bu nedenle, binadaki her bir katın atalet momenti(ölü yük) binanın iki ucundaki çerçeve tarafından taşınmakta ve her bir çerçeveye gelen toplam kütle, binanın sismik kütlesinin arısı olarak alınmıştır.

Kiriş derinlikleri W36 ile sınırlandırılmıştır. Tasarım adımları dayanım, göreceli kat ötelemesi kontrolü ve güçlü kolon - zayıf kat kontrolünden oluşmaktadır. 
Tablo 2 9-katlı çerçeve elemanlarının boyutları

\begin{tabular}{|l|l|l|l|}
\hline Kat & Diş Kolon & İç Kolon & Kiriş \\
\hline $\mathbf{9}$ & W14X257 & W14X311 & W24X55 \\
\hline $\mathbf{8}$ & W14X257 & W14X311 & W27X94 \\
\hline $\mathbf{7}$ & W14X311 & W14X426 & W30X132 \\
\hline $\mathbf{6}$ & W14X311 & W14X426 & W30X132 \\
\hline $\mathbf{5}$ & W14X398 & W14X500 & W33X141 \\
\hline $\mathbf{4}$ & W14X398 & W14X500 & W33X141 \\
\hline $\mathbf{3}$ & W14X455 & W14X550 & W33X141 \\
\hline $\mathbf{2}$ & W14X455 & W14X550 & W33X141 \\
\hline $\mathbf{1}$ & W14X550 & W14X730 & W36X194 \\
\hline Bodrum & W14X550 & W14X730 & W36X194 \\
\hline
\end{tabular}

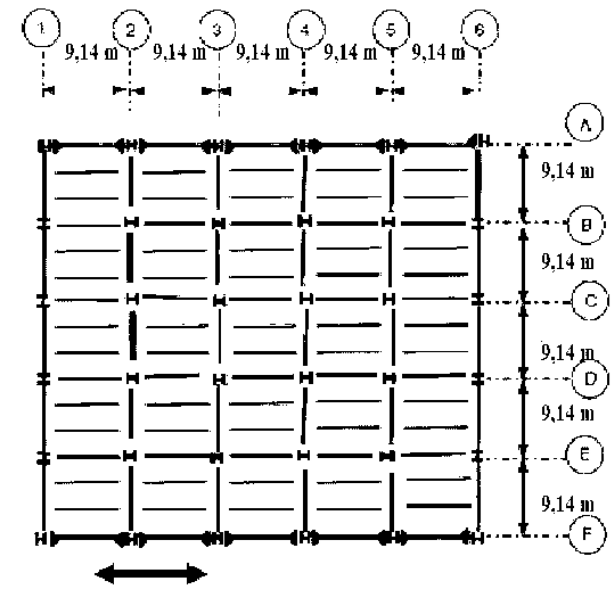

Deprem Yönü

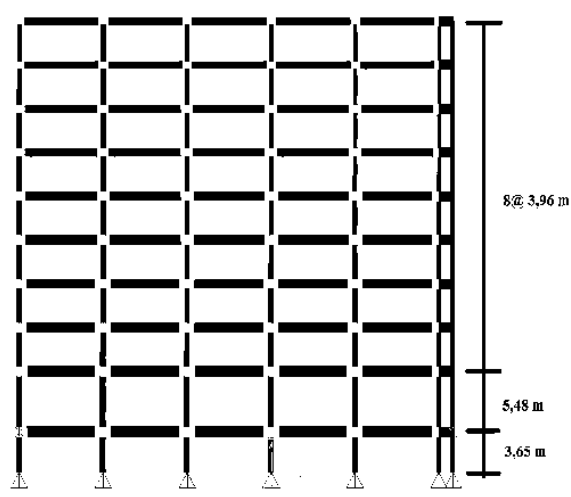

a.Plan

b. A aksı üzerindeki moment

çerçeve

Şekil 4 Katlı çerçeve elemanlarının boyutları 9 katlı çerçevenin plan ve düşey kesit

\subsection{Modellemenin Özellikleri}

Moment çerçevelerin iki boyutlu modelleri SAP2000'de yapılmıştır. Elastik ötesi davranış, elemanların iki ucunda tanımlanan plastik mafsallarla ifade edilmiştir.

Pekleşme etkisi \%5 olarak alınmıştır. PM(eksenel kuvvet-eğilme momenti) etkileşim ilişkisi, AISC Şartnamesinde(2005) önerildiği gibi, kolon elemanlarının eğrilik yüzeyleri olarak kullanılmıştır. Analizlerde panel bölgesi deformasyonu ihmal edilmiştir. Sönüm oranı \% 5 olarak alınmıştır ve doğrusal olmayan dinamik zaman geçmesi analizlerinde 2.ve 4. doğal frekanslarına ait rijitlik ve kütle orantılı Rayleigh sönümü kullanılmıştır.

Çerçevelerde $4.57 \mathrm{~m}$ genişliğindeki yük alanındaki ölü yükün \% 90’1 her kattaki moment çerçevesinin kolonlarının tepesine yerleştirilmiştir. P- $\Delta$ etkisi(“P” yatay yükü 
etkisinde oluşan " $\Delta$ " yatay tepe deformasyonu) değerleri dikkate alınmıştır ve seçilen kolon ve kiriş elemanları kompakt kesitlere sahip olduklarından, yerel burulma etkisi ihmal edilmiştir (Akbaş vd., 2007).

\section{4. Çeliğin Sıcaklıkla İlişkisi}

Yapıdaki taşıyıcı sistemin eğilmelere bükülmelere ve sonuçta da çökmeye neden olacak bir sıcaklığa kadar 1sıtılmasına izin verilmez. Binaların Yangından Korunması Hakkında Yönetmelik (2007-2015) hükümlerine göre, çelik kolon ve kirişlerin yangın durumunda özelliklerini kaybetmemesi için yangına karşı yalıtılması gerekmektedir. Yönetmelikte, çevreye yangın yayma tehlikesi olmayan ve yangin sirasında içindeki yanıcı maddeler yüzünden yapının çelik elemanlarında $540^{\circ} \mathrm{C}$ 'nin üzerinde bir sıcaklık artışına sebep olmayacak bütün çelik yapılar yangına karşı dayanıklı kabul edilmektedir. $\mathrm{Bu}$ sıcaklık mutlak olmayıp, kullanılan çeliğin özelliklerine ve uygulanan yük faktörüne bağlı olarak değişebilir. Yangindan korunma sisteminin, hem mimar hem de inşaat mühendisi tarafından ön tasarım aşamalarında dikkatli bir şekilde göz önüne alınması gerekir.

Isı iletim katsayısı yüksek olan çelik, 1sınma durumunda gerilim sınırını çok kolay aşabilir. Gerilim sınırı aşıldığında gerilme esnekliği kaybolur ve kalıcı şekil değişmeleri meydana gelir. Çok zayıf olan ve basınç altında bulunan yapı kısımları, yüksek sıcaklıklarda taşıma özelliğini kaybeder. Isınan çelik uzar, birleştiği noktalarda değişiklikler meydana getirir ve bazen bütün konstrüksiyonu y1kabilecek güçte kuvvet oluşturur. Sicaklıktan dolayı meydana gelen bu hacim değişiklikleri, çelik kiriş ve çelik kolonların taşıma gücünü kaybetmesine ve çökmesine neden olabilir. Kolonlar ise, genellikle her taraftan 1s1 geçişine açık oldukları için, çökme olasılığı çok yüksek bir yapı elemanıdır. Çok yük taşıyan kolonlardan sadece birinin kırılması bile bütün binanın çökmesi demektir. Bu yüzden yangına karş1 çok dayanıklı olmalıdır.

Çeliğin uzama katsayısı, ahşabın yaklaşık üç katıdır. Örneğin, başlangıçta uzunluğu $5 \mathrm{~m}$. olan $20^{\circ} \mathrm{C}$ sıcaklıktaki çelik taşıyıcı, yangın sebebiyle $640^{\circ} \mathrm{C}$ sicaklığa isındiğında boyu yaklaşık $5 \mathrm{~cm}$. artar. Toplam uzunluk arttıkça taşıyıcıların dayandığ 1 veya uzamadan dolayı ittiği duvarlara büyük güçler uygulanır. $\mathrm{Bu}$ nedenle bu tür yapılar, özellikle yangınlardan dolayı yükselen sıcaklıklar nedeniyle meydana gelen uzamalardan korumak için ulaşılacak sıcaklık hesaplanmalı ve gerekiyorsa yangına karşı yalıtılmalıdır.

Çeliğin çekme mukavemeti başlangıçta 150$300^{\circ} \mathrm{C}$ değerlerinde biraz arttıktan sonra, daha yüksek sıcaklıklarda hızla azalır ve yangınlarda kolayca erişilen $600^{\circ} \mathrm{C}$ sıcaklığında emniyet gerilmesinin altına düşer. Yüksek sıcaklıklarda bağ kuvvetlerinin azalması, çeliğin elastisite modülünün azalmasına neden olur. Elastisite modülünün değeri $20^{\circ} \mathrm{C}$ 'dekine kıyasla, $400^{\circ} \mathrm{C}^{\prime} \mathrm{de} \% 15$ ve $600^{\circ} \mathrm{C}$ 'de ise $\% 40 \mathrm{kadar}$ azalır. Çevre sicaklığına göre mukavemeti ise, sicaklığ $700^{\circ} \mathrm{C}$ olduğunda \% 23 'e, $800^{\circ} \mathrm{C}$ 'de $\% 11^{\prime} \mathrm{e}, 900^{\circ} \mathrm{C}$ 'de $\% 6^{\prime}$ 'ya düşer ve yaklaşık $1500^{\circ} \mathrm{C}$ sıcaklıkta erir. Uzamalar 1sıl gerilmelerin oluşmasına ve normal olarak yüksek sicakliklarda burkulma yapmayan kolonun burkulmasına ve daha düşük taşıma gücü göstermesine neden olabilir (Kılıç, 2017).

Çelik iskeletli yapıların yangın bakımından özel önemi vardır. Bunlarda, yanmazlıktan çok 1sıl şekil değiştirmelerin oluşumu göz önüne alınır. Birçok standart, çelik yapıları 
özel bir sınıf olarak ele almıştır. Çelik yapıların tasarımına ilişkin bilgi veren Eurocode 3 (EN 1993) standartlarının ikinci bölümü, çelik taşıyıcıların yalıtımına ayrılmıştır ve çeşitli hesap yöntemleri verilmiştir. Alanı $5000 \mathrm{~m}^{2}$ den az olan tek katlı yapılar hariç olmak üzere, diğer çelik yapılarda, çeliğin sıcaktan uygun şekilde yalıtılması gerektiği belirtilmektedir. Binanın, kullanım şekline ve yüksekliğine bağlı olarak binanın belli bir süre çökmeden korunması gerekir. Yönetmelikte EK 3/C'ye göre yapıda yağmurlama olup olmamasına, kullanım şekline ve yapı yüksekliğine bağlı olarak yangına dayanım (direnç) süreleri verilmiştir. Yangın dayanım süresi, bir yapı bölümünün belirli bir yangın yükü altında, kendisinden beklenen görevleri yerine getirmeye devam ettiği zaman süresidir. Burada sözü edilen görevler; yüke dayanım, hacim örtme ve 1sıl difüzyonu sinırlama fonksiyonlarıdır. Hacim örten yap1 elemanlarında, ateşe bakmayan arka yüzlerde sıcaklık artmasının $140^{\circ} \mathrm{C}$ 'yi aşmaması ve buralarda kendiliğinden yanabilir gazlar oluşmaması istenir. Eğilmeye çalışan elemanlarda ise sehimlerin artma hızının belirli sınırları aşmaması gerekir.

Çıplak çeliğin de belli bir derece yangına direnci olduğu unutulmamalıdır. Çelik $550^{\circ} \mathrm{C}$ 'de oda sicaklığındaki akma gerilmesinin \%50'sine yaklaşır. Yangın şartlarına, yüklenmeye, bağlantılara, uç baskılara, alanın geometrisine ve benzerine bağlı olarak çıplak çelik o alan için güvenilir olarak varsayılmış tasarım yangınlarına uygun direnç gösterdiği görülmüştür.

Yapılarda çıplak çeliğin kullanıldığı yaygın uygulamalar içinde az katlı binalar, açık otoparklar ve diş yapı elemanları yer alır. Çelik profillerin 1sınma problemindeki en önemli faktörlerden biri de "F/V profil faktörü" adı verilen, aleve maruz kalacak alanın ısınacak kütleye oranıdır. F/V oranı ile yangına dayanım süresi ters orantılı olarak değişir ve $\mathrm{F} / \mathrm{V}$ oranı küçüldükçe yangına dayanım süresi artar.

Yangın direnci olan inşaat çeliği alaşımları, $600^{\circ} \mathrm{C}$ 'de oda sıcaklığındaki akma gerilmesinin 2/3'ünü tutacak şekilde geliştirilmektedir. Bu çeliğe akma gerilmesi üzerine etki yapan molibden gibi elementlerin katılmasıyla sağlanır (Marrion et al., 2004). Bu malzemeyi kullanarak inşa edilmiş birkaç yapı mevcuttur. İlave yangına karşı dayanıklılık derecesi yangına dayanıklı çeliğe, klasik yangına dirençli kaplamaların uygulanmasıyla elde edilebilir.

Yenilik yaratıcı araştırmalar ve gelişmiş üretim uygulamalarıyla yeni çelik formülleri görülmektedir. $\mathrm{Bu}$ yeni çelikler halen Japonya ve diğer Asya ülkelerinde sinırlı kullanım yerleri bulmuştur. Yangına dayanıklı çelikler olarak atıf yapılan bu malzemeler endüstri içinde yer bulmaktadır. Yangına dayanıklı çeliklerin araştırıcıları, bu malzemelerin yüksek sicaklık seviyelerindeki özelliklerinin daha geleneksel çelik formülleriyle karşılaştırıldıklarında daha az mukavemet kaybı gösterdiklerini, ancak yangına dayanıklı çeliklerin pasif koruma önlemlerinin yerini alamayacağını belirtmektedirler. Buna karşıllk bu teknolojinin, yap1 çökmeden önce ilave zaman kazandıracağı ve yapıyı koruyucu malzemelerin iflas etmesinden sonra bile yapının daha uzun süre ayakta kalmasını sağlayacağı kesindir. Yangına dayanıklı çelik kullanılmasının örnekleri Japonya, Çin ve Almanya'da mevcuttur. Sinırlı sayıdaki uygulamalar arasinda otopark, spor salonu, demiryolu istasyonu ve ofis binaları sayılabilir (Kılıç, 2017). 
Çelik için genel bir ilişki Şekil 5' de gösterilmiştir. Sıcaklık yaklaşık $93{ }^{\circ} \mathrm{C}$ ' ye ulaştığında akma gerilme ve kopma gerilme eğrileri doğrusal olmayan eğri çizmeye başlar. Elastisite modülü, akma gerilmesi, kopma gerilmesi sicaklığın artması ile beraber azalır. $426^{\circ} \mathrm{C}-538^{\circ} \mathrm{C}$ aras 1 maksimum azalma düzeyinin an fazla olduğu sıcaklıklardır. Farklı mikro yapı ve kimyasal yapılarından dolayı her çeliğin davranışı birbirinden farklıdır. Çelik göreceli bir biçimde yüksek karbon yüzdesine sahiptir. $150{ }^{\circ} \mathrm{C}$ ile $370{ }^{\circ} \mathrm{C}$ düzeylerinde akma gerilmesi örneğin $\mathrm{Fe} 37$ gibi bir çelikte ortaya çıkabilir. Sıcaklık $204{ }^{\circ} \mathrm{C}^{\prime}$ ye ulaştığında akma gerilmesi ve kopma gerilmesindeki azalma Şekil 6'da görüldüğü gibi süreklilik gösterir. Sıcaklık $1093^{\circ} \mathrm{C}^{\prime}$ ye ulaştığında akma ve kopma gerilmesi en düşük seviyesine ulaşır.

Elastisite modülünün azalması sıcaklığın artması ile doğrusal bir biçimde azalır. 538 $\mathrm{C}$ den itibaren daha hızlı bir biçimde azalma meydana gelir. Daha da önemlisi $260^{\circ} \mathrm{C}$ ile $320^{\circ} \mathrm{C}$ yukarısındaki sıcaklıklarda çelikte ortaya çıkan sünme olarak bilinen plastik deformasyon zamanla artar.

Çoğu çelik yaklaşık $538{ }^{\circ} \mathrm{C}$ aşağısındaki uygulamalarda kullanılır. Isıya maruz kalan çelik $426{ }^{\circ} \mathrm{C}$ aşağısında tutulmalıdır. $\mathrm{Bu}$ uygulamada $93^{\circ} \mathrm{C}, 204^{\circ} \mathrm{C}, 325^{\circ} \mathrm{C}, 426^{\circ} \mathrm{C}$ ve $538^{\circ} \mathrm{C}$ de çeliğin davranışı doğrusal olmayan statik öteleme(push-over) analiz yöntemi ile incelenmiştir.
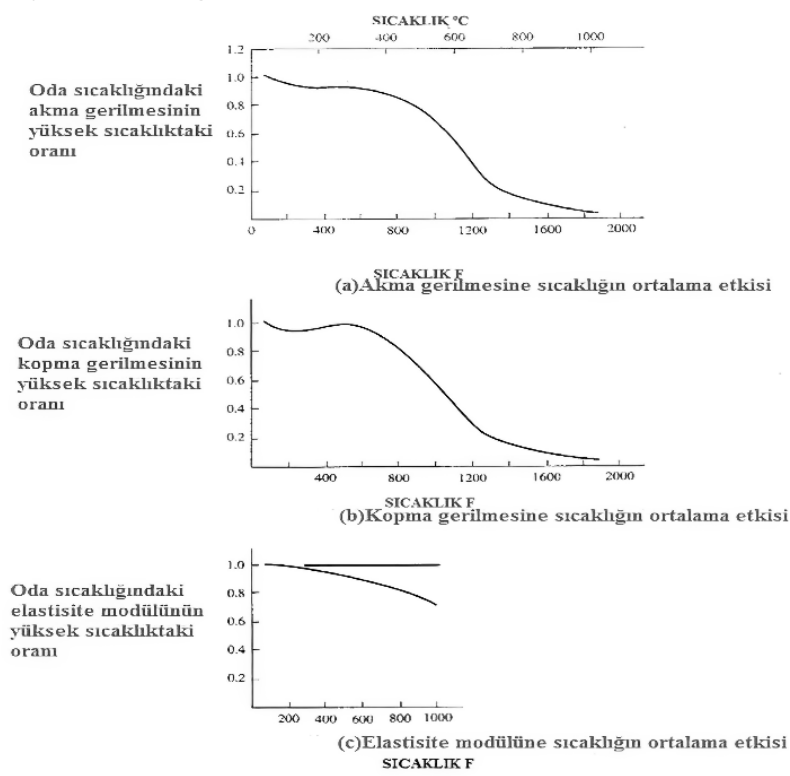

Şekil 5. Yapısal çeliklerin akma gerilmesi, kopma gerilmesi ve elastisite modülleri eğri özelliklerinin yüksek sıcaklıklardaki değişimi (Salmon and Johnson, 1996)

Yukarıdaki grafikten akma gerilmesi, kopma gerilmesi ve elastisite modüllerini tablo

Tablo 3. Çelik sıcaklık tablosu haline getirirsek aşağıdaki gibi elde edilir (Tablo 3).

\begin{tabular}{|l|c|c|c|c|c|c|c|c|c|c|}
\hline Çelik/SIcaklık & $200 \mathrm{~F}$ & $400 \mathrm{~F}$ & $600 \mathrm{~F}$ & $800 \mathrm{~F}$ & $1000 \mathrm{~F}$ & $1200 \mathrm{~F}$ & $1400 \mathrm{~F}$ & $1600 \mathrm{~F}$ & $1800 \mathrm{~F}$ & $2000 \mathrm{~F}$ \\
\hline & $93^{\circ} \mathrm{C}$ & $204^{\circ} \mathrm{C}$ & $325^{\circ} \mathrm{C}$ & $426^{\circ} \mathrm{C}$ & $538^{\circ} \mathrm{C}$ & $649^{\circ} \mathrm{C}$ & $760^{\circ} \mathrm{C}$ & $871^{\circ} \mathrm{C}$ & $982^{\circ} \mathrm{C}$ & $1093^{\circ} \mathrm{C}$ \\
\hline Akma gerilmesi & 0.95 & 0.90 & 0.89 & 0.84 & 0.69 & 0.35 & 0.19 & 0.11 & 0.05 & 0.05
\end{tabular}




\begin{tabular}{|l|l|l|l|l|l|l|l|l|l|l|}
\hline Kopma gerilmesi & 0.96 & 0.99 & 0.95 & 0.82 & 0.57 & 0.26 & 0.17 & 0.09 & 0.04 & 0.03 \\
\hline Elastisite Modülü & 0.99 & 0.96 & 0.90 & 0.80 & 0.70 & 0.49 & 0.24 & 0.05 & 0.03 & 0.025 \\
\hline
\end{tabular}

Yukardaki tablonun yardımıyla çelik için

modülleri $93{ }^{\circ} \mathrm{C}, 204{ }^{\circ} \mathrm{C}, 325{ }^{\circ} \mathrm{C}, 426{ }^{\circ} \mathrm{C}$ ve

SAP2000 programında kullanılan akma

$538{ }^{\circ} \mathrm{C}$ sıcaklıklardaki değerleri aşağıdaki

gerilmesi, kopma gerilmesi ve elastisite

gibidir (Tablo 4).

Tablo 4. Çelik malzeme özelliklerindeki değişim

\begin{tabular}{|c|c|c|c|c|c|c|c|c|c|c|}
\hline $\begin{array}{ll}\text { Çelik / } \\
\text { Sıcaklık }\end{array}$ & $200 \mathrm{~F}$ & $400 \mathrm{~F}$ & $600 \mathrm{~F}$ & $800 \mathrm{~F}$ & $1000 \mathrm{~F}$ & $1200 \mathrm{~F}$ & $1400 \mathrm{~F}$ & $1600 \mathrm{~F}$ & $1800 \mathrm{~F}$ & $2000 \mathrm{~F}$ \\
\hline & $93^{\circ} \mathrm{C}$ & $204^{\circ} \mathrm{C}$ & $325^{\circ} \mathrm{C}$ & $426^{\circ} \mathrm{C}$ & $538^{\circ} \mathrm{C}$ & $649^{\circ} \mathrm{C}$ & $760^{\circ} \mathrm{C}$ & $871^{\circ} \mathrm{C}$ & $982^{\circ} \mathrm{C}$ & $1093^{\circ} \mathrm{C}$ \\
\hline $\begin{array}{l}\text { Akma } \\
\text { gerilmesi }\end{array}$ & $\begin{array}{l}32.75 \\
\mathrm{KN} / \mathrm{cm}^{2}\end{array}$ & $\begin{array}{l}31.02 \\
\mathrm{KN} / \mathrm{cm}^{2}\end{array}$ & $\begin{array}{l}30.68 \\
\mathrm{KN} / \mathrm{cm}^{2}\end{array}$ & $\begin{array}{l}28.95 \\
\mathrm{KN} / \mathrm{cm}^{2}\end{array}$ & $\begin{array}{l}23.78 \\
\mathrm{KN} / \mathrm{cm}^{2}\end{array}$ & $\begin{array}{l}12.06 \\
\mathrm{KN} / \mathrm{cm}^{2}\end{array}$ & $\begin{array}{l}6.55 \\
\mathrm{KN} / \mathrm{cm}^{2}\end{array}$ & $\begin{array}{l}3.79 \\
\mathrm{KN} / \mathrm{cm}^{2}\end{array}$ & $\begin{array}{l}1.72 \\
\mathrm{KN} / \mathrm{cm}^{2}\end{array}$ & $\begin{array}{l}1.72 \\
\mathrm{KN} / \mathrm{cm}^{2}\end{array}$ \\
\hline $\begin{array}{l}\text { Kopma } \\
\text { gerilmesi }\end{array}$ & $\begin{array}{l}43.02 \\
\mathrm{KN} / \mathrm{cm}^{2}\end{array}$ & $\begin{array}{l}44.36 \\
\mathrm{KN} / \mathrm{cm}^{2}\end{array}$ & $\begin{array}{l}42.57 \\
\mathrm{KN} / \mathrm{cm}^{2}\end{array}$ & $\begin{array}{l}36.74 \\
\mathrm{KN} / \mathrm{cm}^{2}\end{array}$ & $\begin{array}{l}25.54 \\
\mathrm{KN} / \mathrm{cm}^{2}\end{array}$ & $\begin{array}{l}11.65 \\
\mathrm{KN} / \mathrm{cm}^{2}\end{array}$ & $\begin{array}{l}7.61 \\
\mathrm{KN} / \mathrm{cm}^{2}\end{array}$ & $\begin{array}{l}4.03 \\
\mathrm{KN} / \mathrm{cm}^{2}\end{array}$ & $\begin{array}{l}1.79 \\
\mathrm{KN} / \mathrm{cm}^{2}\end{array}$ & $\begin{array}{l}1.34 \\
\mathrm{KN} / \mathrm{cm}\end{array}$ \\
\hline $\begin{array}{l}\text { Elastisite } \\
\text { Modülü }\end{array}$ & $\begin{array}{l}19794.85 \\
\mathrm{KN} / \mathrm{cm}^{2}\end{array}$ & $\begin{array}{l}19195.0 \\
\mathrm{KN} / \mathrm{cm}^{2}\end{array}$ & $\begin{array}{l}17995.31 \\
\mathrm{KN} / \mathrm{cm}^{2}\end{array}$ & $\begin{array}{l}15995.83 \\
\mathrm{KN} / \mathrm{cm}^{2}\end{array}$ & $\begin{array}{l}13996.35 \\
\mathrm{KN} / \mathrm{cm}^{2}\end{array}$ & $\begin{array}{l}9797.45 \\
\mathrm{KN} / \mathrm{cm}^{2}\end{array}$ & $\begin{array}{l}4798.75 \\
\mathrm{KN} / \mathrm{cm}^{2}\end{array}$ & $\begin{array}{l}999.73 \\
\mathrm{KN} / \mathrm{cm}^{2}\end{array}$ & $\begin{array}{l}599.84 \\
\mathrm{KN} / \mathrm{cm}^{2}\end{array}$ & $\begin{array}{l}499.86 \\
\mathrm{KN} / \mathrm{cm}\end{array}$ \\
\hline
\end{tabular}

\begin{tabular}{|l|c|}
\hline & $0 \mathrm{~F} / 0^{\circ} \mathrm{C}$ \\
\hline $\begin{array}{l}\text { Akma } \\
\text { gerilmesi }\end{array}$ & $\begin{array}{c}34.47 \\
\mathrm{KN} / \mathrm{cm}^{2}\end{array}$ \\
\hline $\begin{array}{l}\text { Kopma } \\
\text { gerilmesi }\end{array}$ & $\begin{array}{c}44.81 \\
\mathrm{KN} / \mathrm{cm}^{2}\end{array}$ \\
\hline $\begin{array}{l}\text { Elastisite } \\
\text { Modülü }\end{array}$ & $\begin{array}{c}19994.79 \\
\mathrm{KN} / \mathrm{cm}^{2}\end{array}$ \\
\hline
\end{tabular}

\section{Bașlangıç}

değerleri

$\mathrm{Bu}$ tablodan elde edilen değerler grafik olarak Şekil 6'da sunulmuştur. Bu grafikler Şekil 5'deki grafiklerle uyumludur. Tablo 4'deki değerlere uygun olarak yapısal

model modifiye edilerek doğrusal olmayan statik öteleme (push-over) analizleri gerçekleş-tirilmiştir.

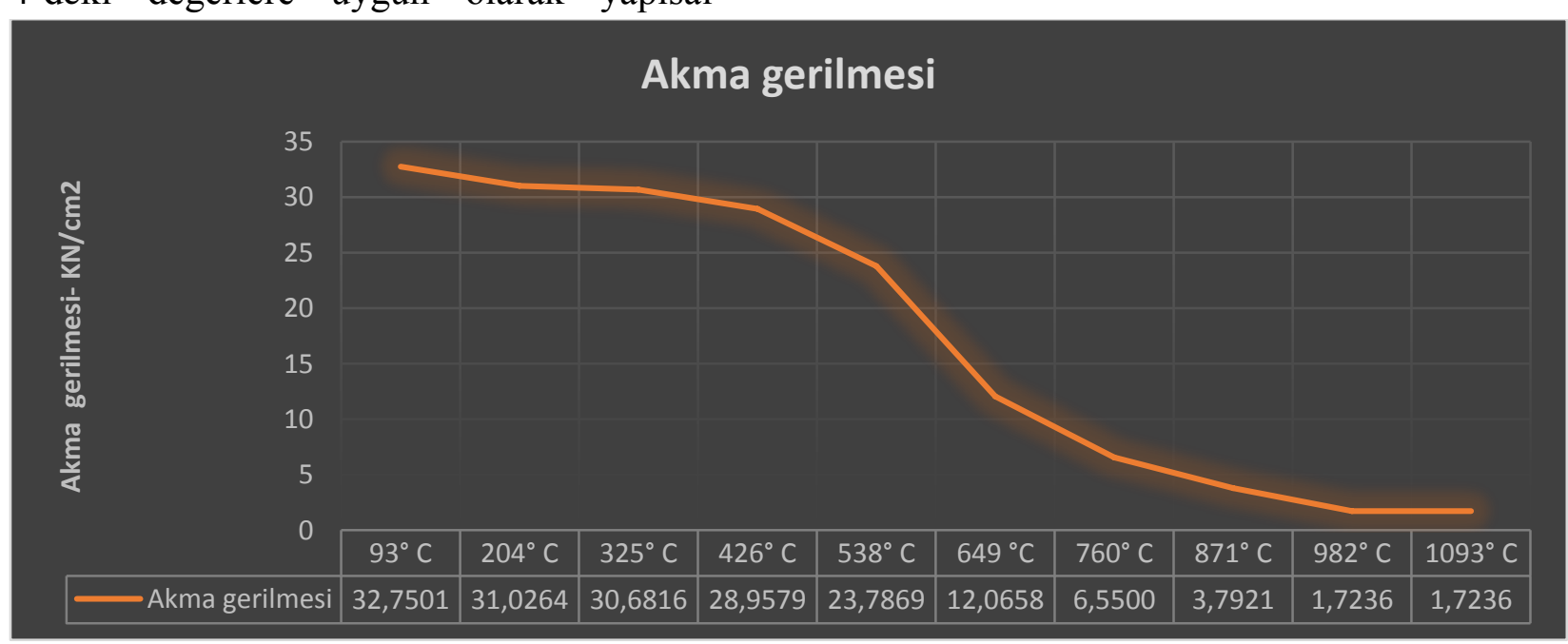

a)Akma gerilmesi 


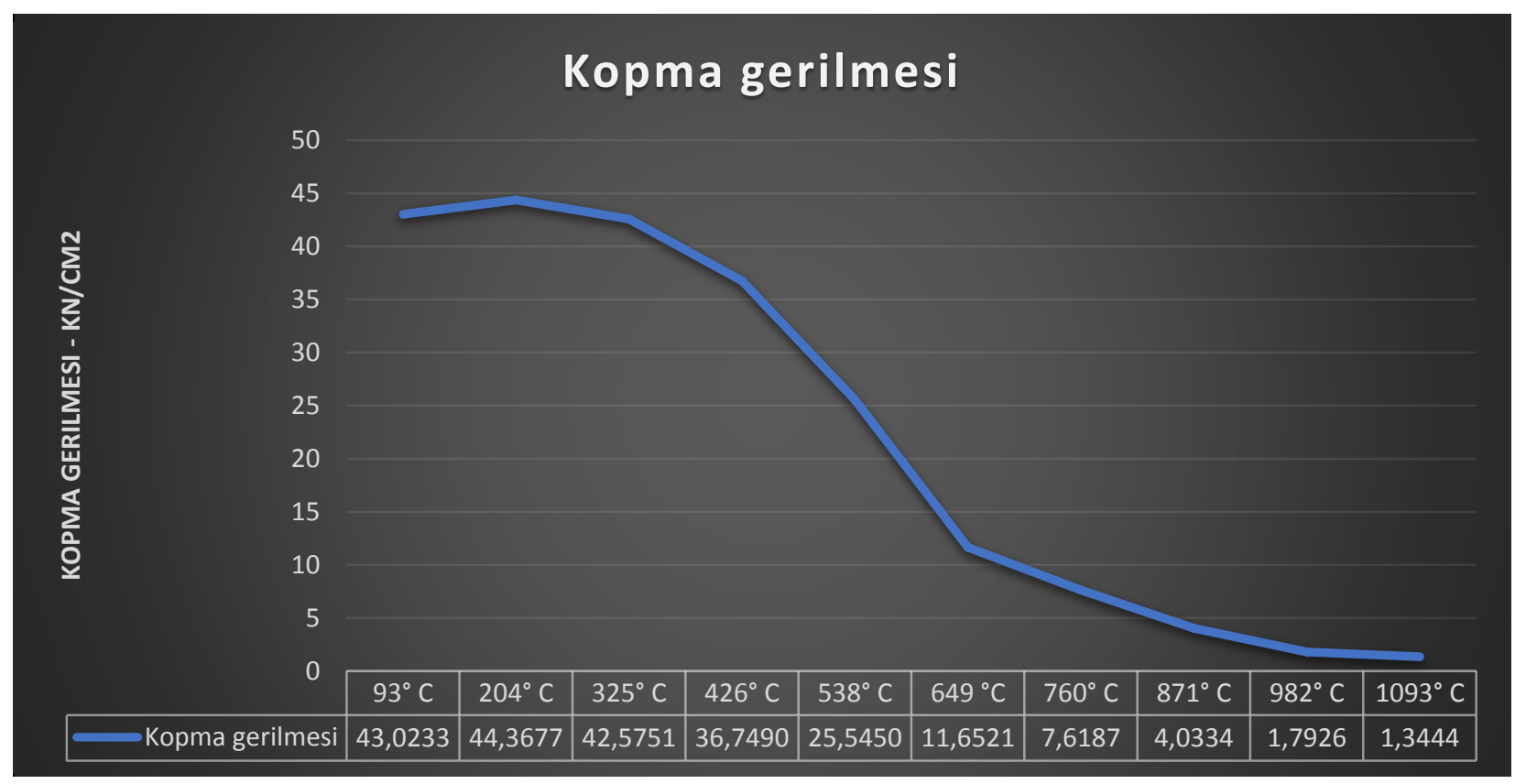

\section{b)Kopma gerilmesi}

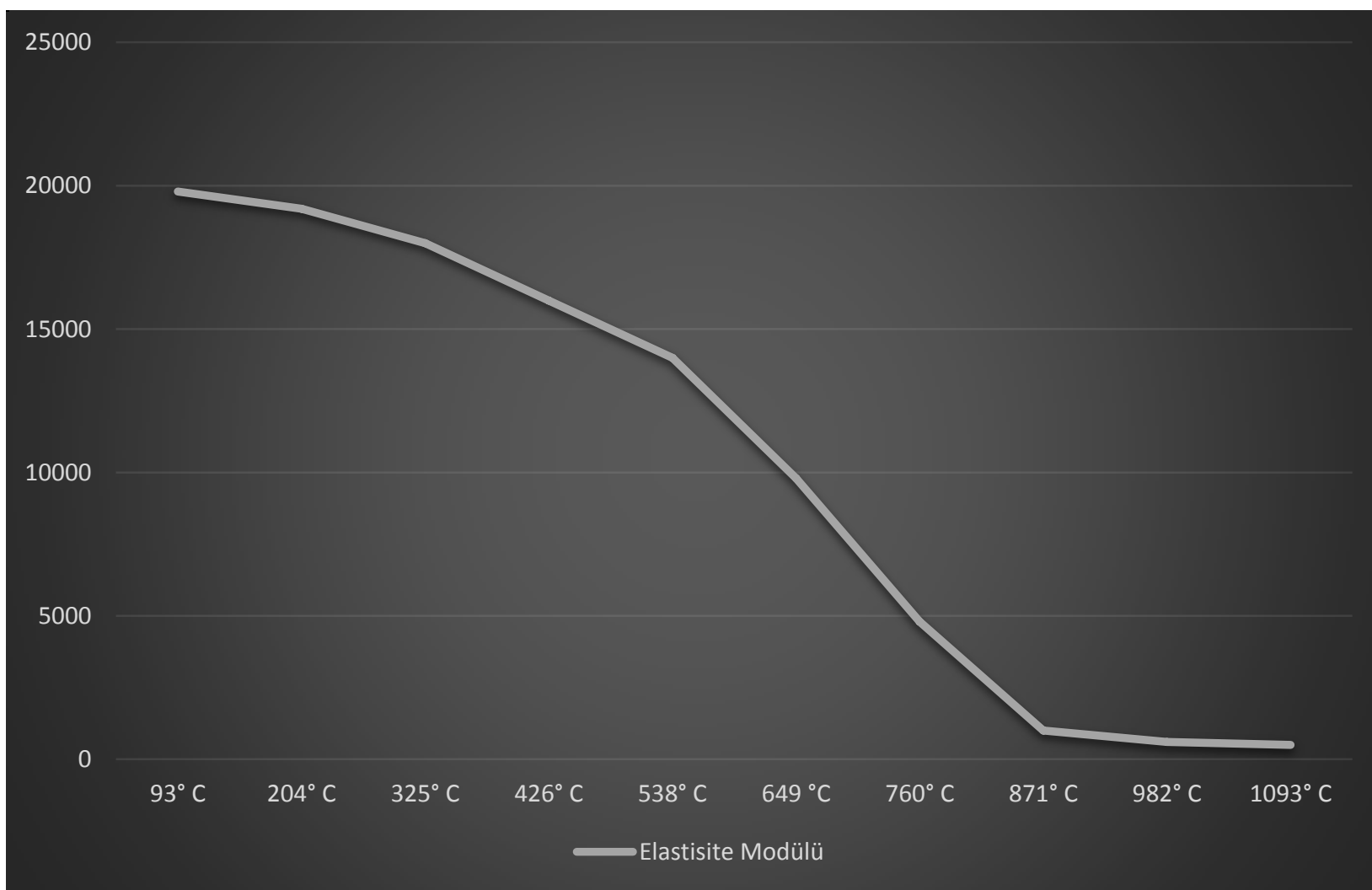

c)Elastisite Modülü - $\mathrm{kN} / \mathrm{mm}^{2}$

Şekil 6 Akma gerilmesi, kopma gerilmesi ve elastisite modüllerinin grafiksel gösterimi 
9 katlı çerçevenin yangına maruz kalması durumunda dayanımı ve rijitliğindeki değişiklikleri incelemek için değişik senaryolar planlanmıştır. $\mathrm{Bu}$ amaçla üretilen senaryolar aşağıdaki gibidir.

\section{Bulgular}

Yangının tüm binayı etkilediği kabul edilmiştir. Tüm binayı saran yangın sonucu oluşan doğrusal olmayan statik öteleme (push-over) analizi sonucu aşağıdadır (Şekil 7).
Meydana gelen dayanım ve rijitliklerdeki değişimlerle önceki üç senaryodaki değişimler karşılaştırıldığında en yüksek azalma oranlarına sahip olduğu Tablo 5'de görülür. Dayanım (Vy) ve başlangıç (elastik) rijitliği $(\mathrm{Ke})$ 'ndeki azalmanın 427 ${ }^{\circ} \mathrm{C}$ ile $538{ }^{\circ} \mathrm{C}$ arasında oldukça yüksek olduğu, $0{ }^{\circ} \mathrm{C}$ ile $538{ }^{\circ} \mathrm{C}$ arasındaki akma sonrası (elasto-plastik) rijitliği (Ks)'ninde neredeyse yarı yarıya azaldığı tespit edilmiştir (Yazgan, 2010).

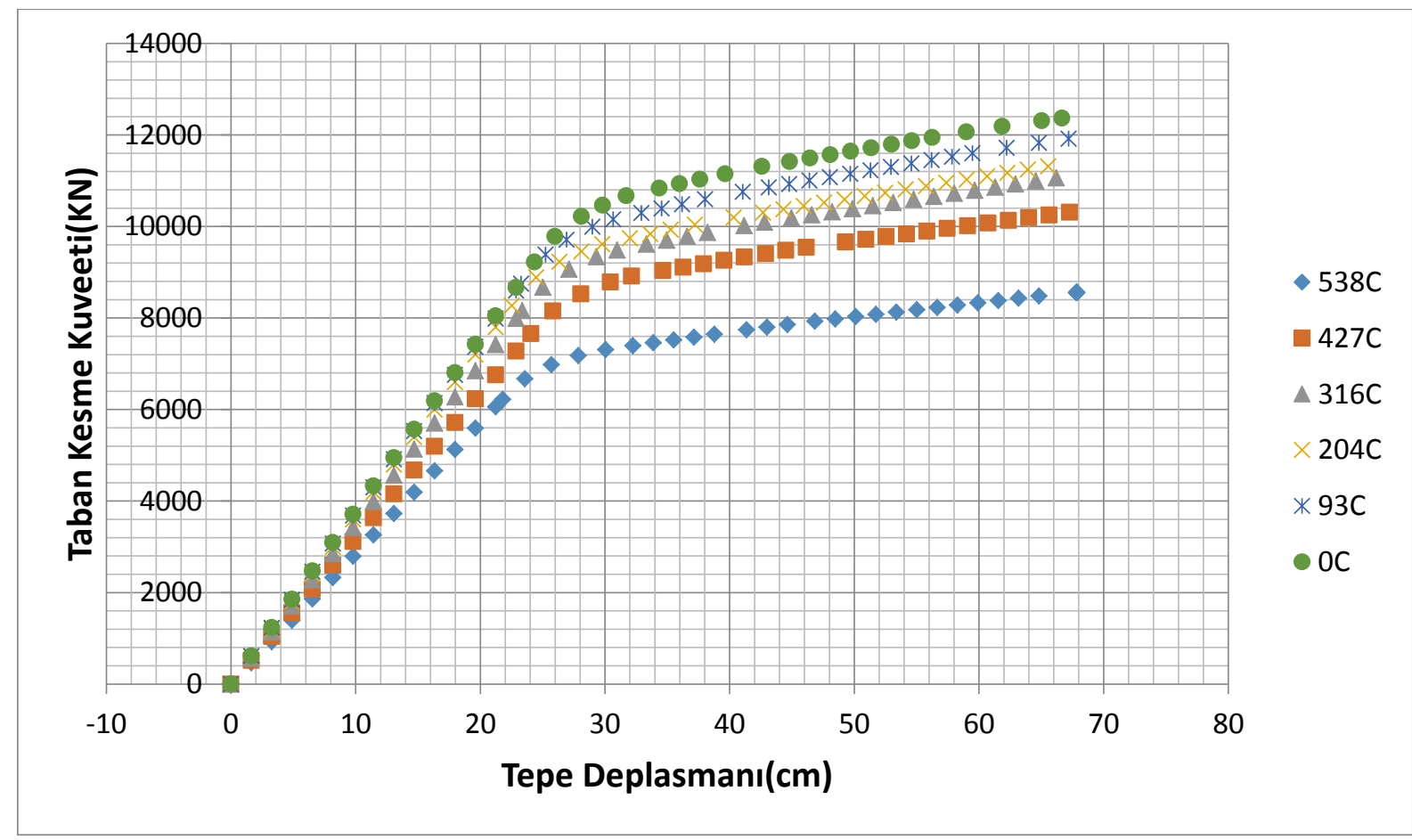

Şekil 7.Tüm binada çıkan yangın sonucu doğrusal olmayan statik öteleme (push-over) analizi

Tablo 5. Tüm binada çıkan yangın sonucu dayanım-rijitlik değişimi

\begin{tabular}{|c|c|c|c|c|c|c|c|c|c|c|c|}
\hline TÜM BİNA & $0^{\circ} \mathrm{C}$ & Değişim & $93^{\circ} \mathrm{C}$ & Değişim & $204^{\circ} \mathrm{C}$ & Değişim & $316^{\circ} \mathrm{C}$ & Değişim & $427^{\circ} \mathrm{C}$ & Değişim & $5538^{\circ} \mathrm{C}$ \\
\hline Dayanım( Vy) & $\begin{array}{l}13000 \\
\mathrm{KN}\end{array}$ & $-\% 8$ & $\begin{array}{l}12000 \\
\mathrm{KN}\end{array}$ & $-\% 4$ & $\begin{array}{l}11600 \\
\mathrm{KN}\end{array}$ & $-\% 3$ & $\begin{array}{l}11333,33 \\
\text { KN }\end{array}$ & $-\% 8$ & $\begin{array}{l}10500 \\
\mathrm{KN}\end{array}$ & $-\% 20$ & $\begin{array}{l}8500 \\
\mathrm{KN}\end{array}$ \\
\hline $\begin{array}{l}\text { Başlangı̣ } \\
\text { Rijitliği(Ke) }\end{array}$ & $\begin{array}{l}389,38 \\
\mathrm{KN} / \mathrm{cm}\end{array}$ & $-\% 9$ & $\begin{array}{l}357,14 \\
\mathrm{KN} / \mathrm{cm}\end{array}$ & $-\% 13$ & $\begin{array}{l}312,5 \\
\mathrm{KN} / \mathrm{cm}\end{array}$ & $-\% 2$ & $\begin{array}{l}306,66 \\
\mathrm{KN} / \mathrm{cm}\end{array}$ & $-\% 1$ & $\begin{array}{l}305,8 \\
\mathrm{KN} / \mathrm{cm}\end{array}$ & $-\% 21$ & $\begin{array}{l}244,49 \\
\mathrm{KN} / \mathrm{cm}\end{array}$ \\
\hline $\begin{array}{l}\text { Akma Sonrası } \\
\text { Rijitliği (Ks) }\end{array}$ & $\begin{array}{l}60 \\
\mathrm{KN} / \mathrm{cm}\end{array}$ & $-\% 8$ & $\begin{array}{l}55,55 \\
\mathrm{KN} / \mathrm{cm}\end{array}$ & $-\% 10$ & $\begin{array}{l}50 \\
\mathrm{KN} / \mathrm{cm}\end{array}$ & $-\% 19$ & $\begin{array}{l}40,74 \\
\mathrm{KN} / \mathrm{cm}\end{array}$ & $-\% 4$ & $\begin{array}{l}39,3 \\
\mathrm{KN} / \mathrm{cm}\end{array}$ & $-\% 7$ & $\begin{array}{l}36,68 \\
\mathrm{KN} / \mathrm{cm}\end{array}$ \\
\hline
\end{tabular}




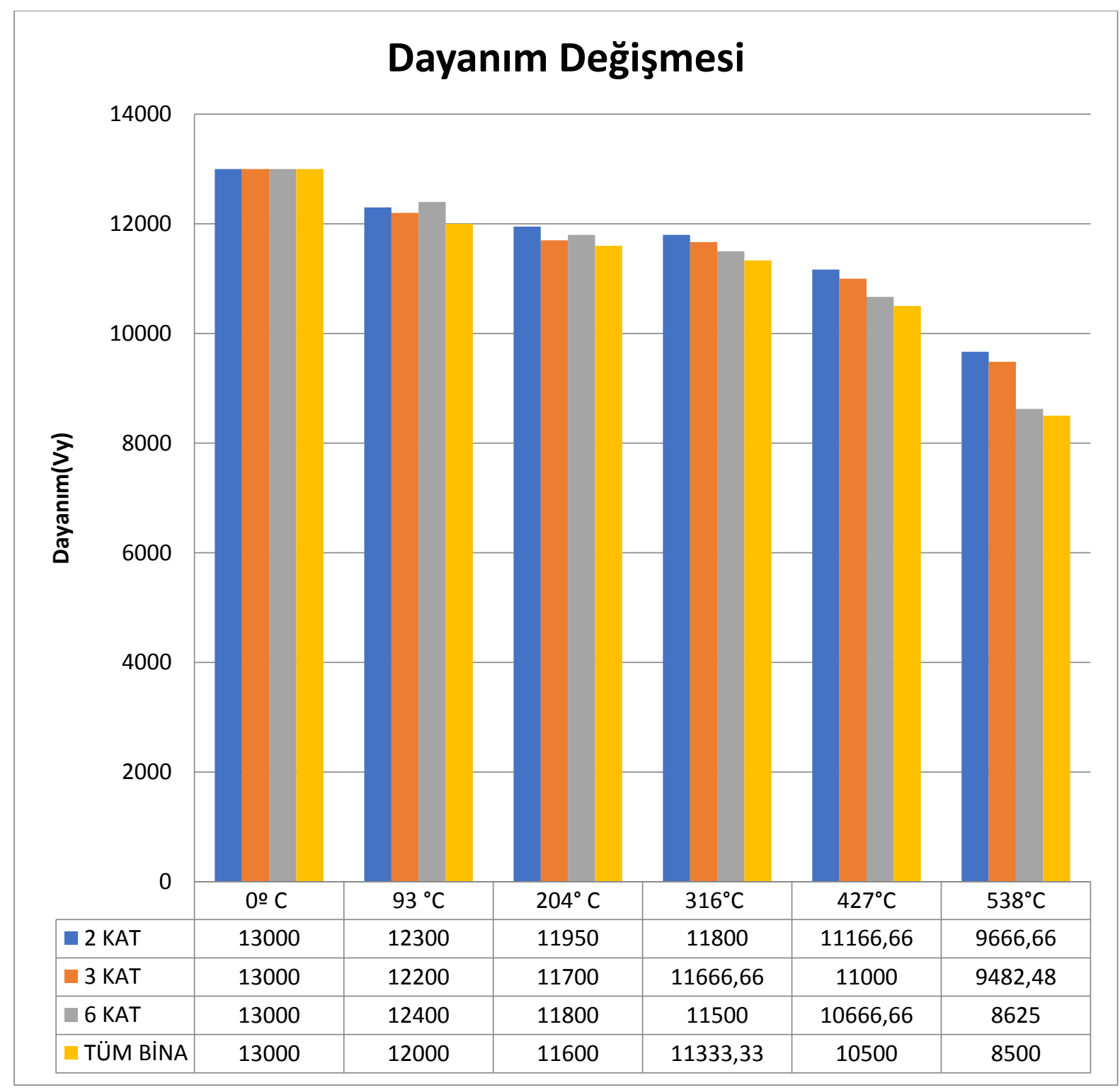

Şekil 8.2-,3-,6 kata kadar ve tüm binada değişik sıcaklıklarda yapının dayanımı- KN

Şekil 8 'de $0^{\circ} \mathrm{C}, 93^{\circ} \mathrm{C}, 204^{\circ} \mathrm{C}, 316^{\circ} \mathrm{C}^{\prime}$ de dayanımdaki azalma $427^{\circ} \mathrm{C}$ ve $538^{\circ} \mathrm{C}^{\prime}$ de meydana gelen dayanım azalmasından daha azdır. Tüm binadaki dayanım azalması diğer katlarda meydana gelen yangınlara oranla önemli bir miktarda fazladır. Bunun nedeni yapının artık kritik bir sıcaklığa ulaşmasıdır. Bina da yeterli yangından korunma önlemlerinin olması gerekir.
Şekil 9'da başlangıç (elastik) rijitliğinin karşılaştırmalı olarak analiz sonucu gösterilmiştir. Yatay yükten kaynaklanan deformasyon rijitlik ölçüsü olarak tanımlanır. Aynı yanal yük etkisindeki elemanlardan, az deformasyon yapan bir elemanın diğerine göre daha rijit olduğu belirtilebilir. 


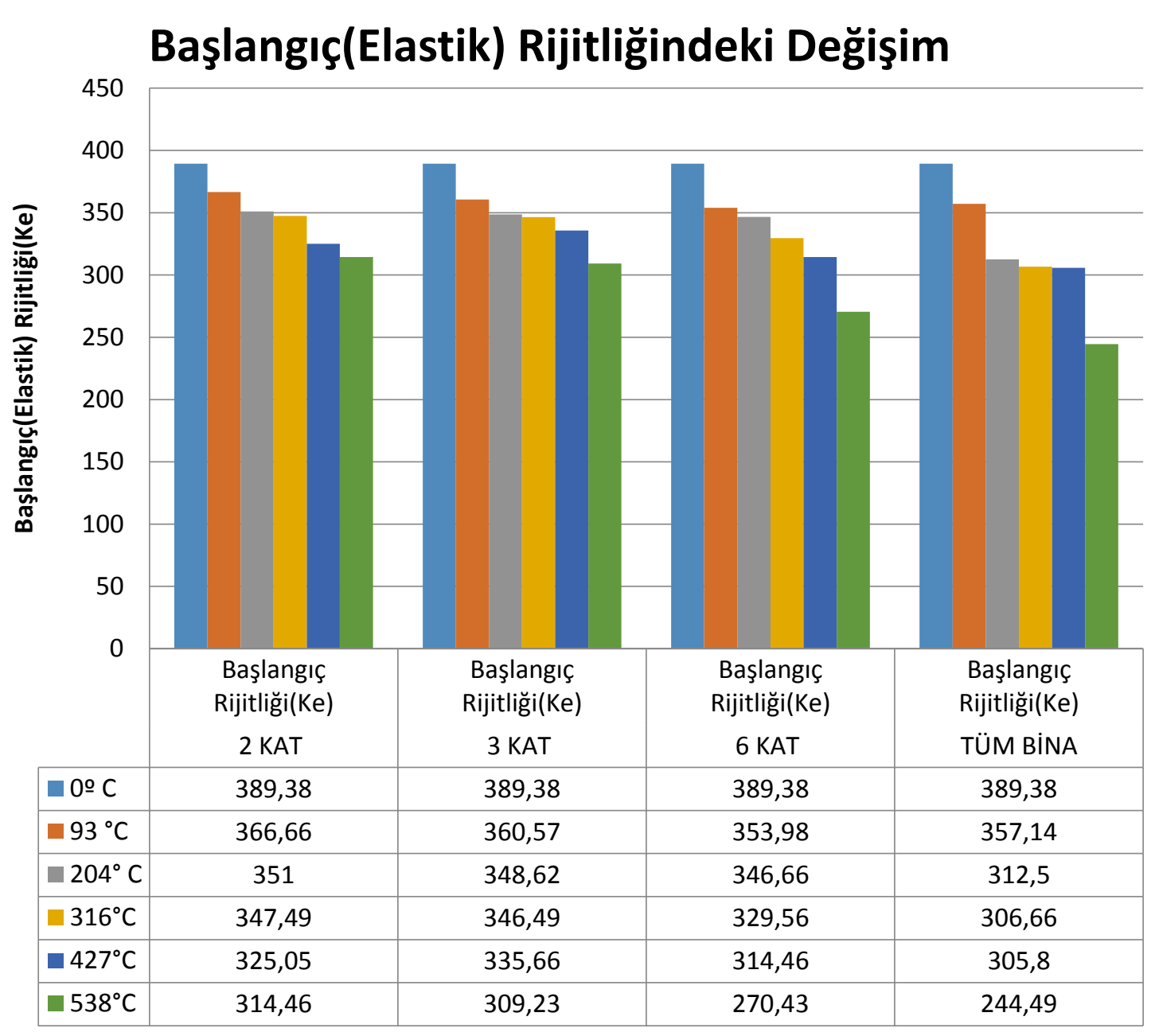

Şekil 9. 2-,3-,6 kata kadar ve tüm binada değişik sıcaklıklarda yapının başlangıç (elastik) rijitliği- KN/cm

Görüldüğü gibi yapıdaki sıcaklık yapıda elastik rijitliği azaltmaktadır. Yangına dayanıklı çelik bir yapı yeterli başlangıç rijitliğine sahip olmalıdır. $\mathrm{Bu}$ kavram ötelenme ve eğilme rijitliği olarak da düşünülebilir.

Büyük yangınların hemen hepsinde zayıf kolonların çökmesi sonucu üst üste yığglan katlar gözlenmiştir. Akma sonrası (Elastoplastik) rijitlik yukarıda görüldüğü gibi sıcaklığın etkisi ile azalmaya devam etmektedir (Şekil 10). Bu sebeple yapıların ve taşıyıcı sistem elemanlarının işlevlerini yerine getirebilmeleri için, işletmede kaldıkları sürede yeterli dayanım ve rijitliğe sahip olmaları ve aynı zamanda, bu süre zarfında tasarım yükünün üstüne çıkabilecek durumları örneğin yangın gibi aşırı yük için de güvenliklerinin bulunması gerekir.

Taşıyıcı eleman boyutlarında kabul edilebilir sınırların dışında oluşabilecek değişiklikler ve malzeme veya birleşim araçlarının dayanımındaki farklilıklar da elemanın gerçek dayanımının tasarım değerinden daha küçük olmasına neden olabilmektedir. 


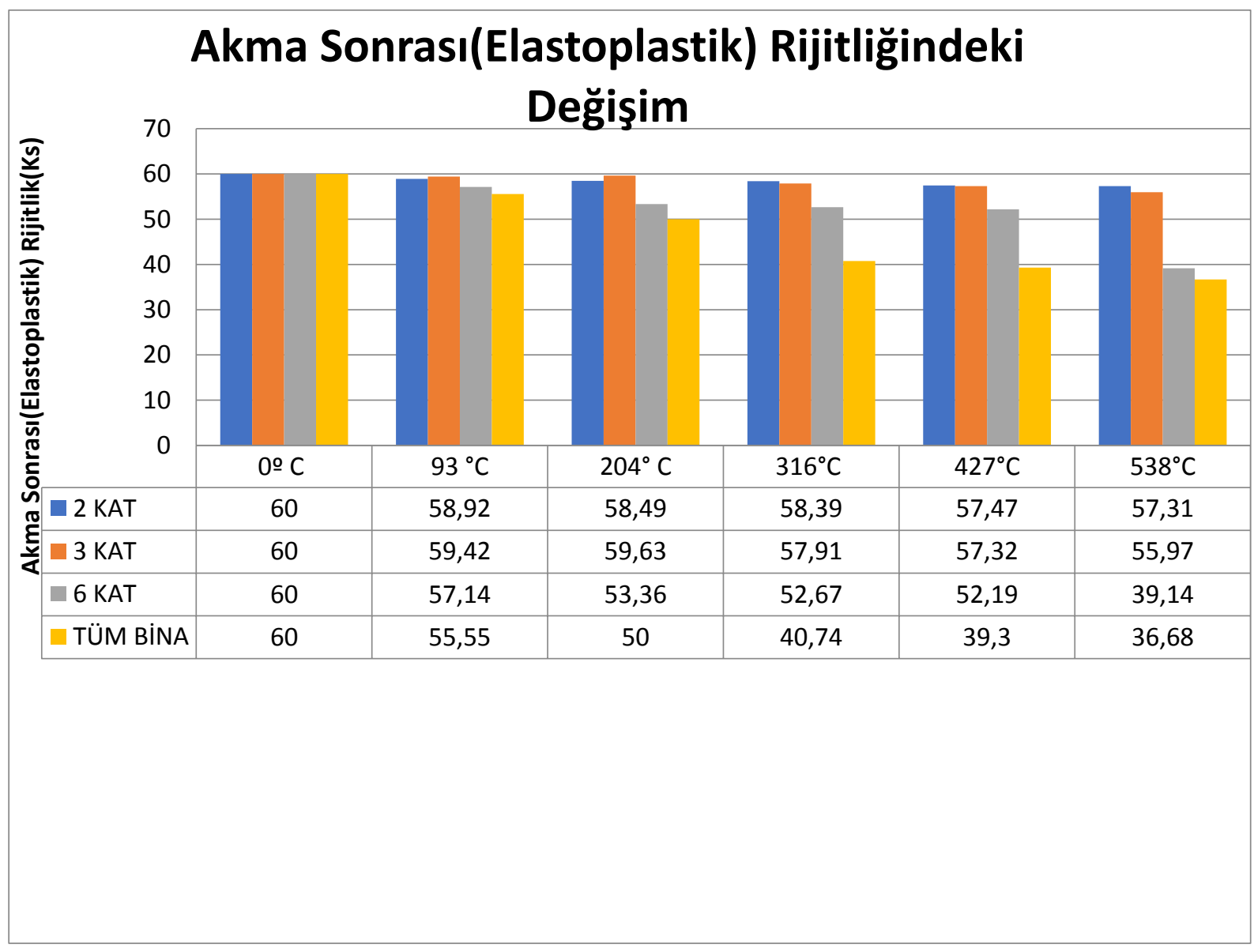

Şekil 10. 2-,3-,6 kata kadar ve tüm binada değişik sıcaklıklarda akma sonrası (elastoplastik) rijitliği-

$\mathrm{KN} / \mathrm{cm}$

Dolayısıyla, yapısal tasarımda hangi karşı yeterli bir güvenliğin bulunması yöntem kullanılırsa kullanılsın, aşırı yükleme veya dayanım azalması olasılı̆̆ına

\section{Tartışma}

Yangına dayanıklı yapı tasarımında, yangının meydana getirdiği olumsuz etkilerinin bilinmesi ve taşı1cı sistemi oluşturan yapı elemanlarının bu deformasyonlara karşı dayanımlı olmalarının yanında, mimari tasarımdan başlayarak yapının taşıyıcı sisteminin oluşturulmasında, yangın dayanımını arttıracak birçok ayrıntının göz önüne alınması gerekmektedir. sağlanmıș olmalıdır.

\section{Sonuç}

Çalışma kapsamında günümüzde kullanımı ve imalatı hızla artan çelik yapıların yangın dayanımı ilgili bir çalışma ortaya konulmuştur. Çelik yapıların çeşitli katlarına kadar çıkan yangınlar sonucundaki değişim doğrusal olmayan statik öteleme (push-over) analizi yöntemiyle Şekil 7'de gösterilen taban kesme kuvveti- tepe deplasmanı grafikleri halinde sunulmuştur. $\mathrm{Bu}$ grafiklerden elde edilen sonuçlar Tablo 5'de dayanım, başlangıç (elastik) rijitliği ve akma 
sonras1 (elastoplastik) rijitlik olarak verilmiştir. $\mathrm{Bu}$ tablolardan elde edilen sonuçların karşılaştırılmalı sonuçları ise Şekil 8, Şekil 9 ve Şekil $10^{\prime}$ da sırasıyla $0^{\circ} \mathrm{C}, 93^{\circ} \mathrm{C}$, $204^{\circ} \mathrm{C}, 316^{\circ} \mathrm{C}, 427^{\circ} \mathrm{C}, 538^{\circ} \mathrm{C}^{\prime}$ de verilmiştir. Böylelikle yangının etkisi değerlendirilmiştir.

İlk olarak dayanım, başlangıç (Elastik) rijitlikleri ve akma sonrası (elastoplastik) rijitlik fazladır ve daha fazla yangın yükü taşımaya zorlandıklarında, tasarım özelliklerine bağlı olarak ya gevrek davranış özellikleri gösterip ani olarak kırılabilirler ve yahut sünek bir davranış ile maruz kaldıkları yükü artan deformasyonlar eşliğinde karşılamaya devam ederler. Bu nedenle, artan sıcaklıklar altında aşılan elastik sınırlar, çeliğin dayanımının azalmasına yol açar. Dayanımda ortaya çıkan başlangıç değerindeki değişme tüm binada çıkan yangın için yaklaşık \% 34.6'lara varan bir azalmaya yol açar. Başlangıç (elastik) rijitlikte ortaya çıkan başlangıç değerindeki değişme tüm binada çıkan yangın için yaklaşık \% 37.2'lere varan bir azalma ortaya çıkarır. Akma sonrası (elastoplastik) rijitlik için başlangıç değerindeki değişme yaklaşık olarak tüm binada çıkan yangın için yaklaşık \% 38.9'lara varan bir azalmaya neden olmuştur. Yangin yüklerine karşı tasarımı yapılmış çelik yapılar sünek bir davranış ile dayanımlarında önemli bir düşme olmaksızın plastik deformas-yonlarını arttırırlar.

\section{Teșekkür}

$\mathrm{Bu}$ çalışmada desteklerini esirgemeyen Gebze Teknoloji Üniversitesi'nden Prof.Dr. Bülent AKBAŞ'a teşekkür ederim.

\section{Kaynaklar}

Akbaş B., Shen J. J., Sutchiewcharn.N., Cai W., Seismic Demands on Column Splices in Special Steel Moment Frames, 8-20, 2007
Bennetts I. D., Thomas I.R., Design of steel structures under fire conditions, Prog. Struct. Engng Mater. 2002; 4:6-17 (DOI: 10.1002/pse.100)

Beitel, J. J., Iwankiw, N. R., "Historical Survey of Multi-Story Building Collapses Due to Fire", FPE 3rd Quarter, 2005

Construction, Living Steel, 2015 URL: http://www.livingsteel.org/structural-safety-

2, (Son Erişim Tarihi:06.08.2019)

Fire protection of steel structures, 2014, URL:http://www.fire-experts.It, (Son Erişim Tarihi: 05.06.2018)

İrtem E., Türker K., Hasgül U., Türk Deprem Yönetmeliğinin Performans Hedeflerinin Lineer Olmayan Statik Analiz Yöntemleri ile Değerlendirilmesi, 2003

Kılıç A., Prof. Dr., Çelik Taşıyıcı Binalar ve Yangın Dayanımı, Mimarlık Dergisi, Sayı 394, 2017

Marrion, C; Custer, Richard L. P.; Johann, Matt; Meacham, Brian, "Materials, Systems and Technologies", NIST Fire Protection of Structural Steel in High-Rise Buildings, Civil Engineering Research Foundation, NIST GCR 04-872, Temmuz 2004

MIT Department of Civil and Environmental Engineering, Design of Steel Structures, 1999

Saha J., Guide Book on Fire Protection of Steel Structures, INSDAG, 3-10, 2004

Salmon C.G., Johnson J.E., Steel Structures, Design and Behaviour, 55- 58, 1996

Strauss L., Yangin Yerinde Yedi Tehlike, 1989 
Sunar Ş., Yangından Korunma ve Bina Yardımcı N., Çelik Yapıların Tasarımı ve Yangin Güvenliği, 1981 Tasarım Yöntemleri,TMH - Türkiye Mühendislik Haberleri, Sayı 435 - 2005/1

Öven V. A. , Parlak İ. Y., Korumasız Çeliğin Yüksek Sicaklıklarda Performans1, Türkiye Mühendislik Haberleri, sayı 427, 79-86, 2003 Yazgan M.T., 2010, "Yangın Geçirmiş Çelik Binaların Dayanımlarının Araştırılması", Yüksek Lisans Tezi, Gebze Teknik Özgünler M., Pasif Yangın Güvenlik Önlemlerinde Etkili Tasarım Üniversitesi, Deprem ve Yapı Anabilim Dalı, Değişkenleri,1994 125-132

Tabak H., Çelik ve Çelik Yapılar, Seminer 6, 2003 